\title{
38. PRELIMINARY RESULTS: MINERALOGY AND GEOCHEMISTRY OF ALTERATION PRODUCTS IN LEG 45 BASEMENT SAMPLES
}

Thierry Juteau, Feyzi Bingöl, Yves Noack, and Hubert Whitechurch, Université Louis Pasteur, Institut de Géologie, Laboratoire de Minéralogie-Pétrographie, 1 rue Blessig, 67084 Strasbourg-Cedex, France

Michel Hoffert and Denis Wirrmann, Université Louis Pasteur, Institut de Géologie, Centre de Sédimentologie et Géochimie de la Surface, 1 rue Blessig, 67084 Strasbourg-Cedex, France

and

Chantal Courtois, Université de Paris-Sud, Laboratoire de Géochimie des Roches Sédimentaires Bâtiment 504, 91405 Orsay, France

\begin{abstract}
In the basaltic rocks from Hole 395A, secondary minerals have developed in primary phenocrysts, in the groundmass, in the vesicles, and in the veinlets. Phenocrysts are weakly altered: plagioclase and clinopyroxene are quite fresh; olivine is partially pseudomorphosed to iddingsite and Mg-carbonate in basalts, and to a celadonite-clay association in dolerites. Glasses are generally devitrified in the groundmass of the basalts; intermediate stages of the palagonitization process have been preserved in some samples. The glassy fragments in hyaloclastic breccias have concentric alteration rims surrounding colorless isotropic fresh glass preserved in the central part of the fragments. The cement of the breccias is mainly zeolitic $(90 \%)$ and calcitic (10\%). Phillipsite, gismondine, and faujasite constitute the zeolitic association: the high water content of these zeolites indicates a low temperature of formation, surely less than $100^{\circ} \mathrm{C}$, possibly around $10^{\circ} \mathrm{C}$. Vesicles and veinlets are mainly filled with phillipsite, calcite, and tri-octahedral smectites (saponite). Detailed study of the coating of an open fracture in a dolerite shows the successive development of (1) green smectite concretions, (2) white opaque stilbite concretions, and (3) scarce translucent phillipsite crystals.

In the ultramafic harzburgites recovered during Leg 45 , the secondary minerals are lizardite, chrysotile, talc, Mg-chlorite, dolomite, aragonite, magnetite, and goethite; the degree of serpentinization ranges from 50 to 100 per cent in the seven samples studied.

Preliminary rare-earth element (R.E.E.) distribution analyses in fresh and altered basalts indicate a remarkable inertness of these elements during halmyrolysis of basalts in oceanic environment.
\end{abstract}

\section{INTRODUCTION}

This paper gathers the preliminary results of studies carried out in France on the detailed mineralogy and geochemistry of alteration products in Leg 45 basement samples:

Mineralogy of basaltic phenocrysts and alteration products of vesicles, veinlets, and glasses from Hole 395A were studied by T. Juteau, Y. Noack, and H. Whitechurch.

Detailed mineralogy of an open fracture in a dolerite from Hole 395A was investigated by M. Hoffert and D. Wirrmann.

Serpentines and associated secondary minerals in ultramafic samples from Holes 395 and 395A were examined by F. Bingöl.

REE distribution in fresh and altered basalts was studies by C. Courtois.
This paper is preliminary: the complete results and discussions concerning these studies will be published later.

\section{SECONDARY MINERALS IN LEG 45 BASALTS}

Thirty-one samples from Hole 395A have been examined: Table 1 gives the sample numbers and depths, thin sections made, and X-ray (Debye-Scherrer) data.

Secondary minerals have developed (1) in primary phenocrysts, (2) in the groundmass, mainly in the glassy zones, (3) in the vesicles, and (4) in the veinlets.

\section{Phenocrysts}

Plagioclase. Plagioclase phenocrysts are remarkably fresh. In the only transformations observed, plagioclases of aphyric basalt samples in the immediate vicinity of veinlets filled with smectites and phillipsite have 
TABLE 1

Leg 45, Hole 395A

\begin{tabular}{|llll}
\hline \\
\hline
\end{tabular}

TABLE 1 - Continued

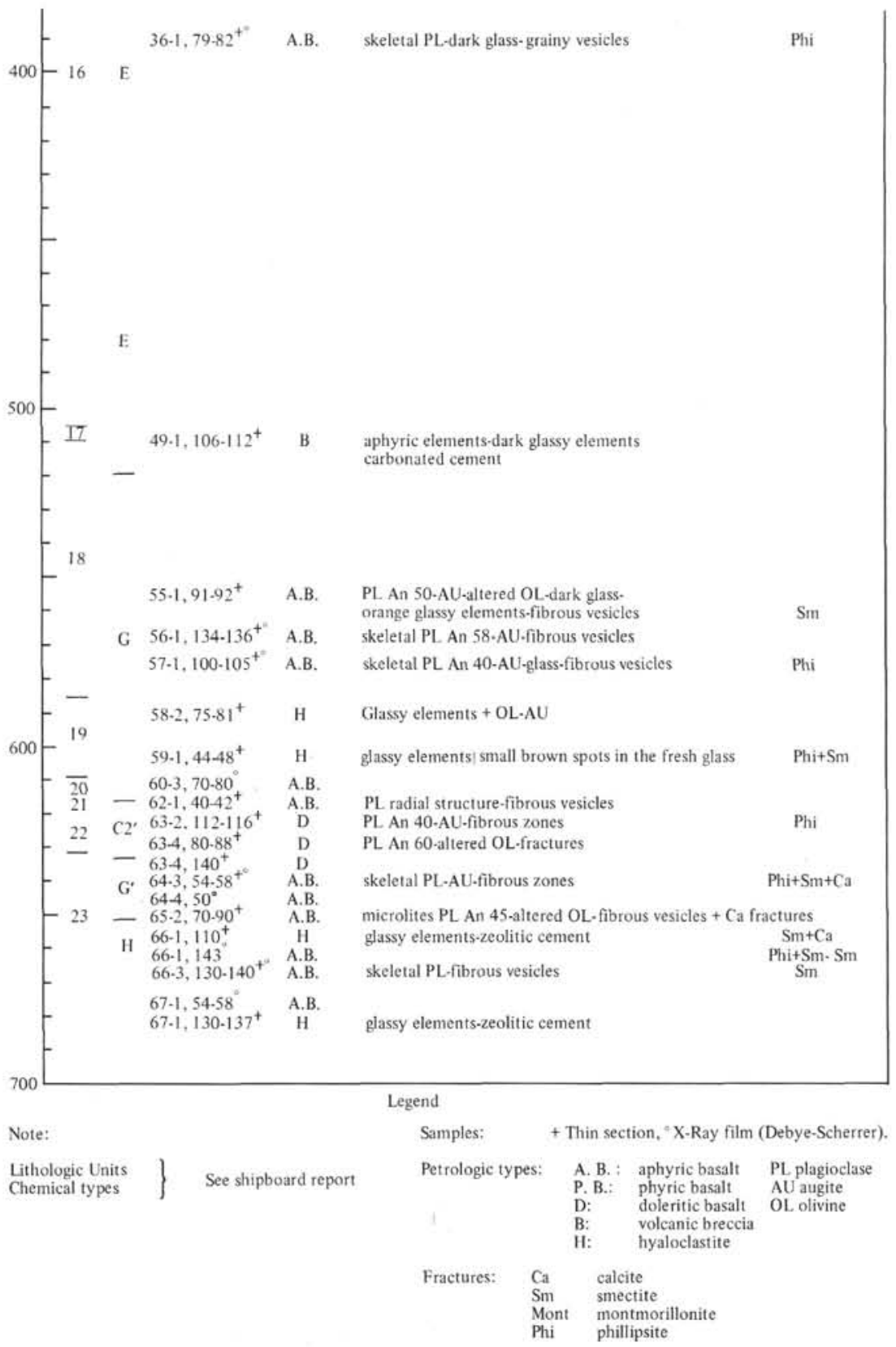


been partially or completely replaced by zeolites and calcite.

Olivine. Olivine phenocrysts are rarely fresh. As usual, they are the most sensitive minerals to alteration: in phyric and aphyric basalts, olivine is partially or completely replaced by iddingsite (mixture of goethite and montmorillonite-type clay). $\mathrm{An} \mathrm{Mg-carbonate}$ (magnesite) sometimes accompanies iddingsite around cores of altered olivines. In the doleritic basalts of the section, the intersertal olivine is transformed to a celadonite-clay association. In all cases, the initial shape of the mineral, skeletal, or idiomorphic, is preserved through pseudomorphosis.

In the hyaloclastic breccia of the section, olivine is always fresh.

Pyroxene. The augitic clinopyroxene remains unaltered. Only small quantities of tiny chlorite lamellae $(<20 \mu \mathrm{m})$ have crystallized around the pyroxenes of the phyric and doleritic basalts.

Conclusion. Primary phenocrysts are weakly altered in Hole 395A. Olivine, the most sensitive mineral, is pseudomorphosed to iddingsite in the basalts, and to a celadonite-clay association in the dolerites. Plagioclase is replaced by calcite and zeolites in the vicinity of smectite-phillipsite veinlets of phyric basalts. Clinopyroxene is fresh. No evolution of alteration with depth has been detected.

\section{Glasses}

Fresh or altered glasses have been found (1) in the groundmass of phyric and aphyric basalts and (2) as fragments in the hyaloclastic breccias.

Groundmass of phyric and aphyric basalts. Primary glasses are scarce. The groundmass is generally devitrified, with delicate submicroscopic pyroxene and $\mathrm{Fe}$-oxides which exhibit "comb" and "feather" shapes. An interstitial palagonitized glass is well developed in Sample 395A-16-1, $142-148 \mathrm{~cm}$. In this orange isotropic glass, round domains about $500 \mu \mathrm{m}$ in size are surrounded by fibrous zeolitic rims; inside these domains, the glass is brown and slightly anisotropic. Radiating zeolite clusters occur between these domains. When the different brown zones join together, the glass is completely palagonitized. The evolution of this alteration is similar to that observed in the hyaloclastites.

Hyaloclastic breccias. This facies is the most interesting for observing all stages of alteration of basaltic glasses. These breccias are made up mainly of glassy fragments with concentric zones of alteration, cemented by zeolites.

The center of the glassy fragments is often fresh colorless or pale yellowish isotropic glass containing some skeletal or sub-automorphic unaltered olivine microphenocrysts (maximum dimension: $1 \mathrm{~mm}$ ). In some fragments, this glass shows evidence of the beginning of alteration: small brownish striated and lobated areas appear here and there in the glass (Plate 1, Figures 1 and 2), often situated around the olivine microphenocrysts. These areas are slightly anisotropic (Plate 1, Figures 3 and 4). In a next stage, these brownish areas are surrounded by a thin fibrous birefringent rim com- posed of smectites and zeolites (Plate 2, Figures 1 and 2 ). Two kinds of concentric alterations have been observed developing around the fresh isotropic central glass:

The first type comprises three "aureoles" (Plate 2, Figures 3 and 4; Plate 3, Figures 1 to 3): (1) an orange isotropic rim, in contact with the fresh glass; (2) an orange-brown anisotropic zone, usually well developed, composed mainly of clay minerals and hydrated altered brownish glass; (3) a fibrous yellow zeolitic and/or chloritic outer rim.

This type of alteration is very similar to the "palagonite neotype" defined and described by Stokes (1971), and to the palagonitized "granules" in the tuffs of Palagonia (Sicily), carefully described by Honnorez (1972).

The second type comprises three tin "aureoles" (Plate 4, Figures 1 to 3): (1) a thin green isotropic rim, in contact with the fresh colorless glass; (2) a thin slightly brownish anisotropic rim; (3) a fibrous zeolitic and/or chloritic outer rim.

This type differs from the former one by the absence of a brownish zone of altered glass between the fresh colorless glass and the fibrous rim; perhaps it is an early stage of the first type.

The cement of the breccias is mainly zeolitic (90\%) and calcitic (10\%); phillipsite occurs as fan-shaped crystals developing on the margin of the glassy fragments (Plate 3, Figure 3). Fine-grained gismondine and faujasite (determined by X-ray diffractometry) are posterior to phillipsite and cement it. The high water content of these zeolites indicates a low temperature of formation, surely less than $100^{\circ} \mathrm{C}$ (Coombs et al., 1959; Senderov, 1965), and perhaps very close to the normal seawater temperatures proposed by Moore (1966) for contemporaneous palagonitization of Hawaiian glasses.

The first chemical data obtained by electron microprobe analysis are not yet satisfactory enough to be published here; they indicate, though, a tholeitic composition for the fresh glass. By comparison, the palagonitized zones show a strong depletion in $\mathrm{CaO}$ and higher contents of $\mathrm{H}_{2} \mathrm{O}$, and $\mathrm{K}_{2} \mathrm{O} ; \mathrm{SiO}_{2}$ is slightly depleted; $\mathrm{Al}_{2} \mathrm{O}_{3}$, total $\mathrm{Fe}$, and $\mathrm{TiO}_{2}$ remain more or less unchanged.

\section{Vesicles}

The following filling associations have been found in the vesicles (see Table 1): (1) phillipsite (Plate 5, Figures 1 and 2), (2) phillipsite + calcite, (3) phillipsite + clays, (4) clays.

No evolution with depth was found.

\section{Veinlets}

The following filling associations have been found in the veinlets (see Table 1): (1) carbonates, (2) phillipsite, (3) phillipsite + iron-rich smectite (nontronite), (4) phillipsite + smectites + carbonates, (5) smectites.

As in the vesicles, phillipsite is the only zeolite found until now in the veinlets (Table 2). The carbonate phase is represented by calcite (Table 3 ). Smectites are 
TABLE 2

Zeolites of Veinlets in Hole 395A Basalts (Debye-Scherrer exposures)

Phillipsite

(ASTM 13-455)

\begin{tabular}{|c|c|c|c|c|c|c|c|c|}
\hline \multirow[b]{3}{*}{ hk1 } & \multicolumn{8}{|c|}{ Sample (Interval in $\mathrm{cm}$ ) } \\
\hline & \multicolumn{2}{|c|}{$36-1,79-82$} & \multicolumn{2}{|c|}{$\begin{array}{c}57-1, \\
100-105\end{array}$} & \multicolumn{2}{|c|}{$60-3,70-80$} & \multicolumn{2}{|c|}{$66-3,143$} \\
\hline & $d(\AA)$ & $\mathrm{I} / \mathrm{I}_{1}$ & $d(\AA)$ & $\mathrm{I} / \mathrm{I}_{1}$ & $d(\AA)$ & $\mathrm{I} / \mathrm{I}_{1}$ & $d(\AA)$ & $\mathrm{I} / \mathrm{I}_{1}$ \\
\hline 101 & 8.22 & 10 & & & 8.22 & 10 & 8.26 & \\
\hline 020 & 7.19 & 85 & 7.22 & 80 & 7.08 & 60 & 7.16 & 80 \\
\hline 012 & 6.43 & 10 & & & & & 6.41 & 20 \\
\hline 121 & & & & & 5.37 & 10 & 5.38 & 30 \\
\hline 022 & & & & & & & 5.02 & 40 \\
\hline 200 & 4.96 & 30 & & & 4.98 & 20 & & \\
\hline 101 & & & & & & & 4.31 & 20 \\
\hline 130 & 4.13 & 70 & & & & & 4.11 & 70 \\
\hline 200 & & & 4.09 & 50 & 4.08 & 50 & & \\
\hline 210 & 3.97 & 10 & & & & & 3.97 & 10 \\
\hline 012 & & & & & & & 3.48 & 10 \\
\hline 140 & & & & & & & 3.28 & 40 \\
\hline 131 & 3.20 & 100 & 3.17 & 100 & 3.18 & 100 & 3.20 & 100 \\
\hline 241 & 2.97 & 30 & 2.98 & 20 & & & 2.96 & 40 \\
\hline 201 & & & & & 2.85 & 10 & & \\
\hline 141 & 2.73 & 50 & & & & & 2.76 & 40 \\
\hline 150 & & & 2.71 & 20 & & & 2.70 & 50 \\
\hline
\end{tabular}

TABLE 3

Carbonates of Veinlets in Hole 395A Basalts (Debye-Scherrer exposures)

\begin{tabular}{|c|c|c|c|c|c|c|c|c|c|c|}
\hline \multicolumn{11}{|c|}{$\begin{array}{c}\text { Calcite } \\
\text { (ASTM 5-586) }\end{array}$} \\
\hline \multirow[b]{3}{*}{ hkl } & \multicolumn{10}{|c|}{ Sample (Interval in $\mathrm{cm}$ ) } \\
\hline & \multicolumn{2}{|c|}{$\begin{array}{c}15-2, \\
110-113\end{array}$} & \multicolumn{2}{|c|}{$\begin{array}{c}15-4, \\
120-124\end{array}$} & \multicolumn{2}{|c|}{$\begin{array}{c}32-1 \\
122-128\end{array}$} & \multicolumn{2}{|c|}{$64-3,54-58$} & \multicolumn{2}{|c|}{$66-1,143$} \\
\hline & $d(A)$ & $1 / I_{1}$ & $d(A)$ & $1 / I_{1}$ & $d(\AA)$ & $1 / l_{1}$ & $d(A)$ & $\mathrm{I} / \mathrm{I}_{1}$ & $\mathrm{~d}(\mathrm{~A})$ & $I / I_{1}$ \\
\hline & 3.86 & 5 & & & 3.84 & 20 & 3.86 & 30 & & \\
\hline 104 & 3.04 & 100 & 3.02 & 100 & 3.01 & 100 & 3.03 & 100 & 3.05 & 100 \\
\hline 06 & 2.88 & 5 & & & 2.82 & 10 & & & & \\
\hline 110 & 2.51 & 5 & 2.50 & 10 & 2.50 & 20 & & & & \\
\hline 113 & 2.28 & 5 & 2.57 & 20 & 2.27 & 50 & 2.28 & 20 & 2.28 & 10 \\
\hline 202 & 2.10 & 5 & 2.09 & 10 & 2.08 & 30 & 2.09 & 10 & 2.11 & 10 \\
\hline 108 & & & & & 1.90 & 50 & 1.91 & 20 & 1.90 & 10 \\
\hline & 1.86 & 5 & 1.88 & 20 & 1.86 & 10 & 1.87 & 10 & & \\
\hline $212-211$ & 1.62 & 5 & & & 1.60 & 10 & & & & \\
\hline & 1.53 & 5 & & & & & & & 1.53 & 10 \\
\hline & & & & & 1.34 & & & & & \\
\hline 2010 & & & & & 1.33 & & & & & \\
\hline $218-306$ & & & & & 1.29 & & & & & \\
\hline $220-1112$ & & & & & 1.23 & & & & & \\
\hline 21410 & & & & & 1.18 & & & & & \\
\hline & & & & & 1.14 & & & & & \\
\hline $\begin{array}{l}2014 \\
3012-231\end{array}$ & & & & & $\begin{array}{l}1.08 \\
1.00\end{array}$ & & & & & \\
\hline
\end{tabular}

mainly of the trioctahedral type; they are represented by the Mg-rich type saponite (Table 4). The dioctahedral type of montmorillonite has been found in one veinlet, where it occurred alone (Table 5).

\section{Coating of an Open Fracture}

The coating of an open fracture in a doleritic basalt (Sample 395A-63-4, 80-88 cm) has been investigated in detail. The fracture is coated by several types of secondary minerals.

Plate 6 (Figures 1 and 2) shows the existence of three kinds of minerals with different colors:
1) a thin pale green coating less than $0.1 \mathrm{~mm}$ thick, with mamelon shapes, covering the whole surface of the fracture;

2) white opaque minerals forming radiating spherules, rather abundant and irregulary disposed over the surface;

3) scarce white and translucent slab minerals.

Each type of concretion has been observed under the scanning electron microscope (CAMECA-07). Indications on the chemistry of these minerals were obtained by energy-dispersive spectrometry (TRACOR System). X-ray Debye-Scherrer exposures were also made.

Plate 7 shows the morphological aspect of the green concretions. They consist of the juxtaposed and anastomosing small spherules or glomerules, the diameters of which are about $0.1 \mathrm{~mm}$. Their surface is made of "folded sheets." In section, these spherules present a more massive radiating structure. That type of morphology is very similar to that described by Person (1976) as minerals of the smectite group. Chemical components of these glomerules are mainly $\mathrm{Fe}, \mathrm{Ca}, \mathrm{Si}$, $\mathrm{Al}$, and Mn. Debye-Scherrer exposures confirm that these minerals are smectites.

Plate 8 shows the morphological aspect of the white opaque concretions. These are "fusiform" balls, with an average diameter of $1 \mathrm{~mm}$. They are composed of slabs or scales with a "roofing tile" disposition. Careful examination of these slabs shows the existence of reentrant angles in the middle part of the structures, indicating that each scale is probably made of two twinned minerals. These structures are analogous to those described by Mumpton and Ormsby (1976). Chemical components of these scales are mainly $\mathrm{Ca}, \mathrm{Si}$, and $\mathrm{Al}$. They grow over the green material, and their genesis is therefore posterior. Debye-Scherrer exposures indicate that these concretions are stilbite.

Plate 9 shows the morphological aspect of the scarce translucent mineral. During observation with the SEM, this mineral became opaque and split into several fragments. Each fragment is made by the piling up of very thin parallel lamellae. Chemical components of this mineral are $\mathrm{K}, \mathrm{Si}, \mathrm{Al}, \mathrm{Na}$, and some Ca. Debye-Scherrer exposures indicate phillipsite.

In conclusion, the open fracture of the sample studied has been coated by three minerals that developed in the following order: (1) smectites, (2) stilbite, (3) phillipsite.

This order of appearance of the secondary minerals is identical to that described by Honnorez (1972) for the submarine alteration of basaltic glasses at Palagonia (Sicily).

\section{SECONDARY MINERALS IN LEG 45 HARZBURGITES}

Seven samples of more or less serpentinized harzburgites gave been examined. The degree of serpentinization ranges from 50 to 100 per cent. Table 6 gives the secondary paragenesis and degree of serpentinization for each sample. 
TABLE 4

Trioctaedral Smectites of Veinlets in Hole 395A Basalts

(Debye-Scherrer exposures, completed by diffractograms)

\begin{tabular}{|c|c|c|c|c|c|c|c|c|c|c|c|c|c|c|c|}
\hline \multirow[b]{4}{*}{ hkl } & \multirow{2}{*}{\multicolumn{12}{|c|}{$\begin{array}{l}\begin{array}{l}\text { Smectite: Saponite } \\
\text { (ASTM 11-56) }\end{array} \\
\text { Sample (Interval in } \mathrm{cm} \text { ) }\end{array}$}} & \multicolumn{3}{|c|}{$\begin{array}{l}\text { Smectite: Saponite } \\
\text { (ASTM 13-86) }\end{array}$} \\
\hline & & & & & & & & & & & & & \multirow[b]{3}{*}{ hkl } & \multirow{2}{*}{\multicolumn{2}{|c|}{$\begin{array}{c}66-3, \\
130-140 \\
\end{array}$}} \\
\hline & \multicolumn{2}{|c|}{$56-1,134-136$} & \multicolumn{2}{|c|}{$64-3,54-58$} & \multicolumn{2}{|c|}{$60-3,70-80$} & \multicolumn{2}{|c|}{$66-1,143$} & \multicolumn{2}{|c|}{$66-3,54-58$} & \multicolumn{2}{|c|}{$66-3,130-140$} & & & \\
\hline & $d(\AA)$ & $\mathrm{I} / \mathrm{I}_{1}$ & $d(\AA)$ & $\mathrm{I} / \mathrm{I}_{1}$ & $d(\AA)$ & $\mathrm{I} / \mathrm{I}_{1}$ & $d(\AA)$ & $\mathrm{I} / \mathrm{I}_{1}$ & $d(\AA)$ & $\mathrm{I} / \mathrm{I}_{1}$ & $d(\AA)$ & $\mathrm{I} / \mathrm{I}_{1}$ & & $d(\AA)$ & $\mathrm{I} / \mathrm{I}_{1}$ \\
\hline 001 & 12.80 & 100 & 14 & 100 & 12.62 & 100 & 12.99 & 100 & 13.59 & 100 & 13.58 & 100 & 001 & 12.98 & 100 \\
\hline 110,020 & 4.57 & 50 & 4.55 & 50 & 4.55 & 50 & 4.57 & 50 & 4.55 & 50 & 4.61 & 30 & 110,120 & 4.58 & 50 \\
\hline 130,200 & 2.56 & 80 & & & 2.56 & 40 & 2.54 & 50 & 2.56 & 20 & 2.54 & 50 & & 3.69 & 60 \\
\hline 310,150 & & & & & 1.73 & & & & 1.73 & 20 & & & 130,200 & 2.55 & 10 \\
\hline 330,060 & 1.53 & 80 & 1.53 & 50 & 1.53 & 70 & 1.53 & 80 & 1.53 & 50 & 1.53 & 50 & & 2.22 & 10 \\
\hline 260,400 & & & & & 1.32 & 30 & 1.32 & 30 & 1.32 & 10 & 1.32 & 20 & & 2.07 & 30 \\
\hline 350,170 & & & & & 1.28 & 10 & & & & & & & 008 & 1.84 & 30 \\
\hline 190,530 & & & & & 0.99 & 10 & & & 0.99 & 10 & & & & 1.74 & 20 \\
\hline \multirow[t]{2}{*}{390,600} & & & & & 0.88 & 10 & & & 0.88 & 10 & & & 330,060 & 1.54 & 80 \\
\hline & & & & & & & & & & & & & & $\begin{array}{l}1.32 \\
1.28\end{array}$ & $\begin{array}{l}10 \\
20\end{array}$ \\
\hline
\end{tabular}

TABLE 5

Dioctaedral Smectites of Veinlets in Hole 395A Basalts (Debye-Scherrer exposures, completed by diffractograms)

\begin{tabular}{c|rr}
\hline \multicolumn{2}{c}{$\begin{array}{c}\text { Montmorillonite } \\
\text { (ASTM 13-259) }\end{array}$} \\
\hline \multicolumn{3}{c}{ Sample (Interval in cm) } \\
\hline \multirow{4}{*}{ hkl } & \multicolumn{2}{|c}{$64-4,50$} \\
\cline { 2 - 3 } & $\mathrm{d}(\AA)$ & $\mathrm{I} / \mathrm{I}_{1}$ \\
\hline & 13.59 & 100 \\
& 4.47 & 50 \\
& 3.20 & 50 \\
& 2.53 & 40 \\
\hline
\end{tabular}

All samples contain both lizardite and chrysotile (Figure 1) with the classical mesh structure around olivine relicts (Plate 10, Figures 1 and 2). Enstatite is pseudomorphosed by bastite, a fibrous variety of lizardite (Plate 10, Figure 3). Veinlets are filled by chrysotile, talc (Plate 10, Figure 4), Mg-rich chlorite (Plate 10, Figure 5), and carbonates (both dolomite and aragonite (Plate 10, Figure 6) have been found). Serpentines are accompanied by a "dust" of tiny magnetite and/or goethite grains.

Plates 11 and 12 show the morphological aspect, with associated microdiffractograms, of the secondary minerals listed above.

\section{REE DISTRIBUTION IN FRESH AND ALTERED BASALTS}

It has been shown that during continental alteration, the rare-earth elements exhibit very homogeneous behaviour (Ronov et al., 1967). Recent studies have shown that the diverse layers in alteration profiles exhibit a rare-earth distribution generally identical to that of the underlying mother-rock (Steinberg and Courtois, 1976).

The aim of the present study is to determine whether this remarkable inertness of the REE family
TABLE 6

Secondary Paragenesis and Degree of Serpentinization for Harzburgite Samples From Site 395

\begin{tabular}{|c|c|c|c|c|}
\hline $\begin{array}{l}\text { Sample } \\
\text { Location }\end{array}$ & Rock Name & $\begin{array}{l}\text { Primary } \\
\text { Minerals }\end{array}$ & $\begin{array}{l}\text { Secondary } \\
\text { Minerals }\end{array}$ & $\begin{array}{c}\text { Degree of } \\
\text { Serpentinization }\end{array}$ \\
\hline $\begin{array}{l}395 \mathrm{~A}-4-2, \\
45-50 \mathrm{~cm} \# 2\end{array}$ & $\begin{array}{l}\text { Serpentinized } \\
\text { harzburgite }\end{array}$ & $\begin{array}{l}\text { Enstatite } \\
\text { Olivine }\end{array}$ & $\begin{array}{l}\text { Chrysotile } \\
\text { Lizardite } \\
\text { "Bastite" } \\
\text { Talc (veinlets) }\end{array}$ & $80 \%$ \\
\hline $\begin{array}{l}395-18-2, \\
139-141 \mathrm{~cm} \\
\# 17 \mathrm{f}\end{array}$ & $\begin{array}{l}\text { Partly serpenti- } \\
\text { nized } \\
\text { lherzolite }\end{array}$ & $\begin{array}{l}\text { Orthopyroxene } \\
\text { Clinopyroxene } \\
\text { Olivine } \\
\text { Chromite }\end{array}$ & $\begin{array}{l}\text { Chrysotile } \\
\text { Lizardite } \\
\text { "Bastite" } \\
\text { Magnetite }\end{array}$ & $50 \%$ \\
\hline $\begin{array}{l}395-18-2, \\
62-70 \mathrm{~cm} \# 15\end{array}$ & $\begin{array}{l}\text { Serpentinized } \\
\text { harzburgite }\end{array}$ & $\begin{array}{l}\text { Enstatite } \\
\text { Olivine } \\
\text { relicts }\end{array}$ & $\begin{array}{l}\text { Chrysotile } \\
\text { Lizardite } \\
\text { "Bastite" } \\
\text { Magnetite and } \\
\text { Goethite } \\
\text { Carbonates (vein- } \\
\text { lets): } \\
\text { (Dolomite) }\end{array}$ & $80 \%$ \\
\hline $\begin{array}{l}395-18-1, \\
142-145 \mathrm{~cm} \# 2 \mathrm{i}\end{array}$ & $\begin{array}{l}\text { Serpentinized } \\
\text { harzburgite }\end{array}$ & $\begin{array}{l}\text { Enstatite } \\
\text { Olivine }\end{array}$ & $\begin{array}{l}\text { Chrysotile } \\
\text { Lizardite } \\
\text { "Bastite" } \\
\text { Magnetite and } \\
\text { Goethite }\end{array}$ & $70 \%$ \\
\hline $\begin{array}{l}395-18-1 \\
101-106 \mathrm{~cm}\end{array}$ & $\begin{array}{l}\text { Serpentinized } \\
\text { harzburgite }\end{array}$ & $\begin{array}{l}\text { Enstatite } \\
\text { Olivine }\end{array}$ & $\begin{array}{l}\text { Chrysotile } \\
\text { Lizardite } \\
\text { "Bastite" } \\
\text { Magnetite and } \\
\text { Goethite }\end{array}$ & $70 \%$ \\
\hline $\begin{array}{l}395 \mathrm{~A}-4-1, \\
100-105 \mathrm{~cm}=9\end{array}$ & $\begin{array}{l}\text { Serpentinite } \\
\text { Very oxidized }\end{array}$ & $\begin{array}{l}\text { Bastite } \\
\text { Enstatite }\end{array}$ & $\begin{array}{l}\text { Chrysotile } \\
\text { Lizardite } \\
\text { "Bastite" }\end{array}$ & $100 \%$ \\
\hline $\begin{array}{l}395-18-2, \\
7-10 \mathrm{~cm} \approx 2\end{array}$ & Serpentinite & $\begin{array}{l}\text { Olivine } \\
\text { relicts, } \\
\text { Enstatite }\end{array}$ & $\begin{array}{l}\text { Chrysotile } \\
\text { Lizardite } \\
\text { Carbonates (vein- } \\
\text { lets): } \\
\text { Aragonite }\end{array}$ & $95 \%$ \\
\hline
\end{tabular}

can also be found during submarine alteration of basalts, or whether a fractionation occurs during halmyrolysis in oceanic environment.

As a first step, we tried to select some of the more representative samples of fresh and altered basalts, and selected the following samples for REE analysis:

\section{Hole 395:}

15-1, 112-119 cm \#8C: fresh basalt

15-1, 37-40 cm \#5: altered basalt 

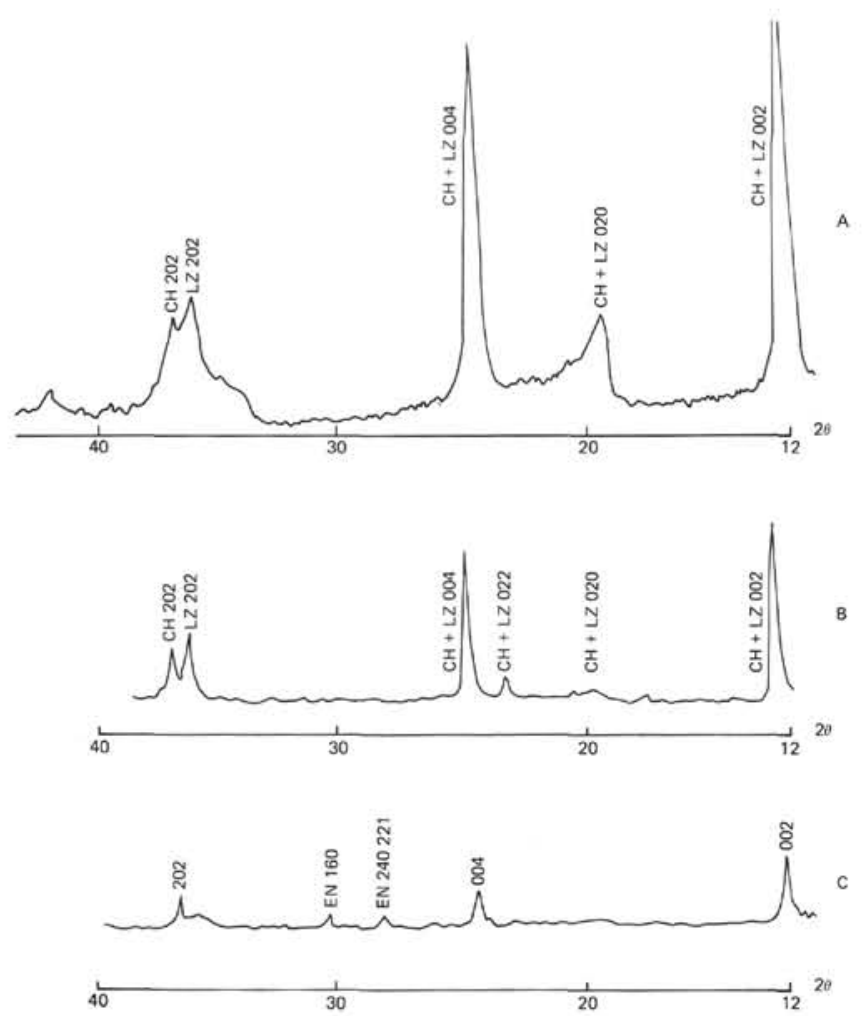

Figure 1. Diffraction tracings of serpentines: (A) chrysotile + lizardite (Sample 395A-4-2, 45-50 cm 2); (B) chrysotile + lizardite (Sample 395-18-1, 101-106 cm 2g); (C) chrysotile + enstatite (Sample 395-18-1, $142-145 \mathrm{~cm} \mathrm{2i})$.

\section{Hole 395A:}

3-1, 140-142 cm \#6 fresh basalt

3-1, 100-102 $\mathrm{cm} \# 4$ altered basalt

$33-2,112-118 \mathrm{~cm} \# 14$ fresh basalt and its alteration rim.

\section{Hole 396:}

15-1, 80-88 cm \#7A fresh basalt, alteration rim and a third outer zone, honey-colored, probably palagonitized glass.

REE have been analyzed by neutron activation, using the method of chemical separation described by Treuil et al. (1973). The results given in Table 7 show classical ratios of REE (30 to $60 \mathrm{ppm}$ ) for oceanic basalts. The absolute ratios for altered basalts are identical to those for fresh material: it seems there is no dilution or concentration during halmyrolysis.

The REE distribution curves are built following the classical normalization diagrams of Coryell et al. (1963). The REE ratios are normalized to chondrites for fresh basalt samples (Figure 2) and for altered basalts that are not directly in contact with fresh material (Figure 3).

For the two samples where a separation has been made, the normalization has been made relative to the corresponding fresh basalt (Figure 4).
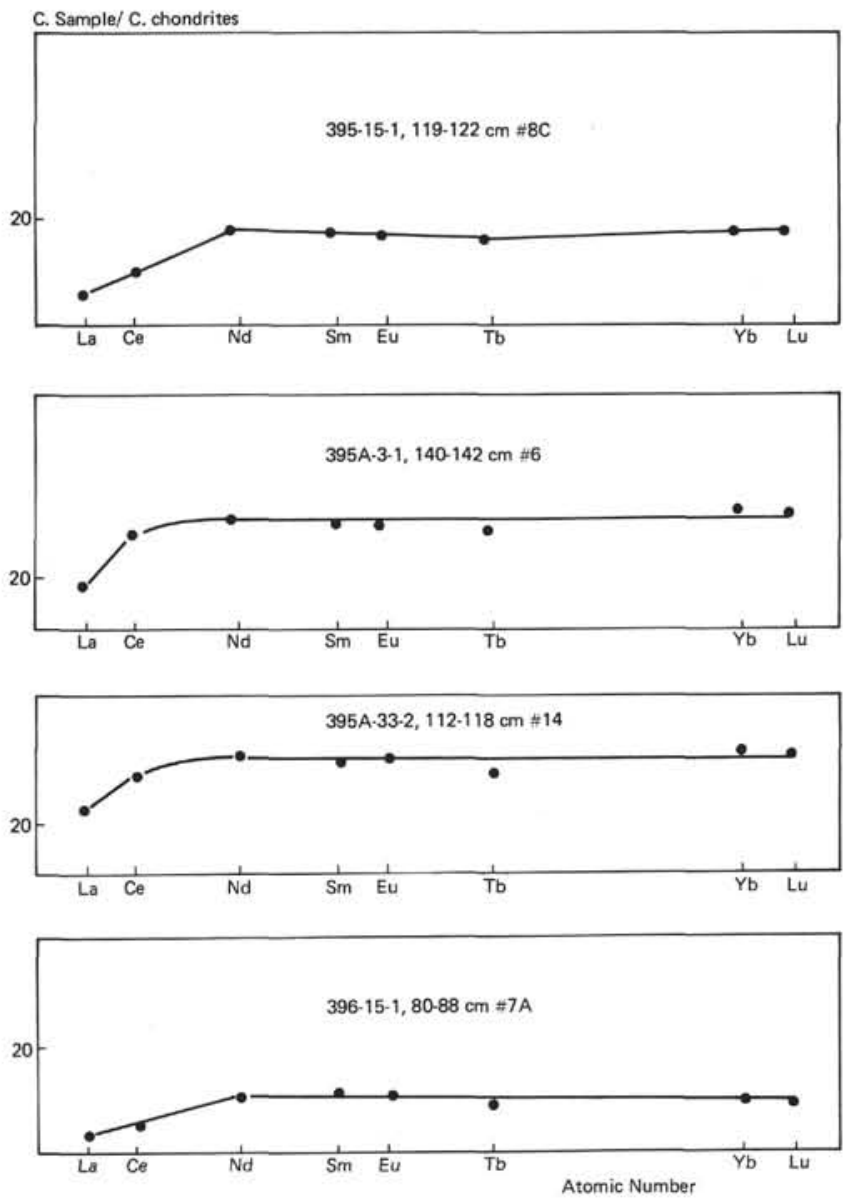

Figure 2. REE curves normalized to chondrites for fresh basalts.

The REE distribution in fresh basalts shows a fractionation with impoverishment in light REE especially for $\mathrm{La}$ and $\mathrm{Ce}$. That kind of profile is characteristic of oceanic tholeiites (Frey and Haskin, 1964).

In altered basalts, the distribution curves normalized to chondrites are identical to the curves for fresh basalts, except for Sample 395A-3-1 \#4, which is not impoverished in light REE. In the two samples where both fresh and altered zones of the same piece were analyzed, the curves normalized to the fresh basalts have a completely flat profile. These curves, with ordinate 1 , show that no fractionation occurred. It seems, therefore, that REE have a homogeneous geochemical behavior during submarine alteration.

The superficial altered glass of Sample 396-15-1, \#7A is a peculiar case. Relative to the underlying fresh basalt, its REE distribution curve presents a clear fractionation, with impoverishment in heavy REE. This fractionation probably reflects differences in mobility of REE, and is related to the progressive decrease, with increasing atomic weight, of the stability constants of these elements in solution. This observation, however, must still be considered in the context of mineralogical and geochemical analysis of this sample for a more precise interpretation. 
TABLE 7

REE Contents (ppm)

\begin{tabular}{llrrrrrrrrr}
\hline \multicolumn{2}{c}{ Sample (Interval in cm) } & $\mathrm{La}$ & $\mathrm{Ce}$ & $\mathrm{Nd}$ & $\mathrm{Sm}$ & $\mathrm{Eu}$ & $\mathrm{Tb}$ & $\mathrm{Yb}$ & $\mathrm{Lu}$ & $\mathrm{Total}$ \\
\hline 395-15-1, 119-122 cm \#8C & Fresh basalt & 4.1 & 11.2 & 11.1 & 3.6 & 1.3 & 0.88 & 3.6 & 0.65 & 36 \\
\hline $395-15-1,37-40 \mathrm{~cm} \# 5$ & Altered basalt & 3.8 & 9.2 & 3.3 & 3.3 & 1.2 & 0.82 & 3.3 & 0.57 & 25 \\
\hline 395A-3-1, 140-142 cm \#6 & Fresh basalt & 6.2 & 20.7 & 16.8 & 5.3 & 1.98 & 1.3 & 5.7 & 1.0 & 59 \\
\hline $395 \mathrm{~A}-3-1,100-102 \mathrm{~cm} \# 4$ & Altered basalt & 9.1 & 19.4 & 14.4 & 5.2 & 1.85 & 1.2 & 4.3 & 0.72 & 56 \\
\hline \multirow{2}{*}{$395 \mathrm{~A}-33-2,112-118 \mathrm{~cm} \# 14$} & Fresh basalt & 7.5 & 22.2 & 19.5 & 5.9 & 2.2 & 1.4 & 6.4 & 1.1 & 66 \\
& Altered basalt & 7.6 & 21.7 & 18.4 & 6.3 & 2.4 & 1.5 & 6.2 & 1.1 & 65 \\
\hline \multirow{2}{*}{ 396-15-1, 80-88 cm \#7A } & Fresh basalt & 3.75 & 9.4 & 8.7 & 2.76 & 1.05 & 0.7 & 2.6 & 0.5 & 29 \\
& Altered basalt & 3.73 & 9.1 & 7.6 & 2.95 & 1.08 & 0.65 & 2.8 & 0.46 & 28 \\
& Altered glass (?) & 4.03 & 12.0 & 5.7 & 1.22 & 0.42 & 0.22 & 0.97 & 0.14 & 25 \\
\hline
\end{tabular}
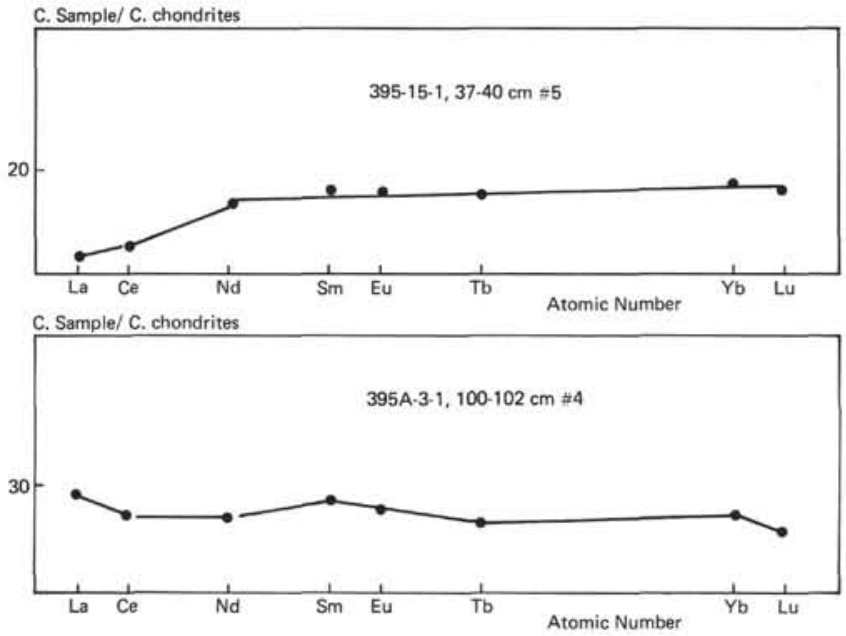

Figure 3. REE curves normalized to chondrites for altered basalts.

The present results must be considered with caution for the following reasons:

First, the small number of samples analyzed prevents any generalization of the conclusions of this study.

Second, the separation of pure phases is probably incomplete and a "contamination," even weak, of altered material by fresh material introduces an error that can be significant for trace elements.

Last, the alteration of the basalts is very superficial, so that the ratio between mobilized elements and residual material is too weak for the geochemical evolution of the REE distribution to be detected.

It is necessary to analyze samples where alteration is more intense, and particulary to follow the REE evolution during palagonitization of basaltic glasses.

\section{ACKNOWLEDGMENTS}

We want to thank Professor G. Dunoyer de Segonzac for his critical review of this paper.

\section{REFERENCES}

Coombs, D. S., Ellis, A. J., Fyfe, W. S., and Taylor, A. M., 1959. The zeolite facies with comments on the interpretation of hydrothermal syntheses, Geochim. Cosmochim. Acta, 17, p. 58-107.

Coryell, C. D., Chase, J. W., and Winchester, J. W., 1963. A procedure for geochemical interpretation of terrestrial rare
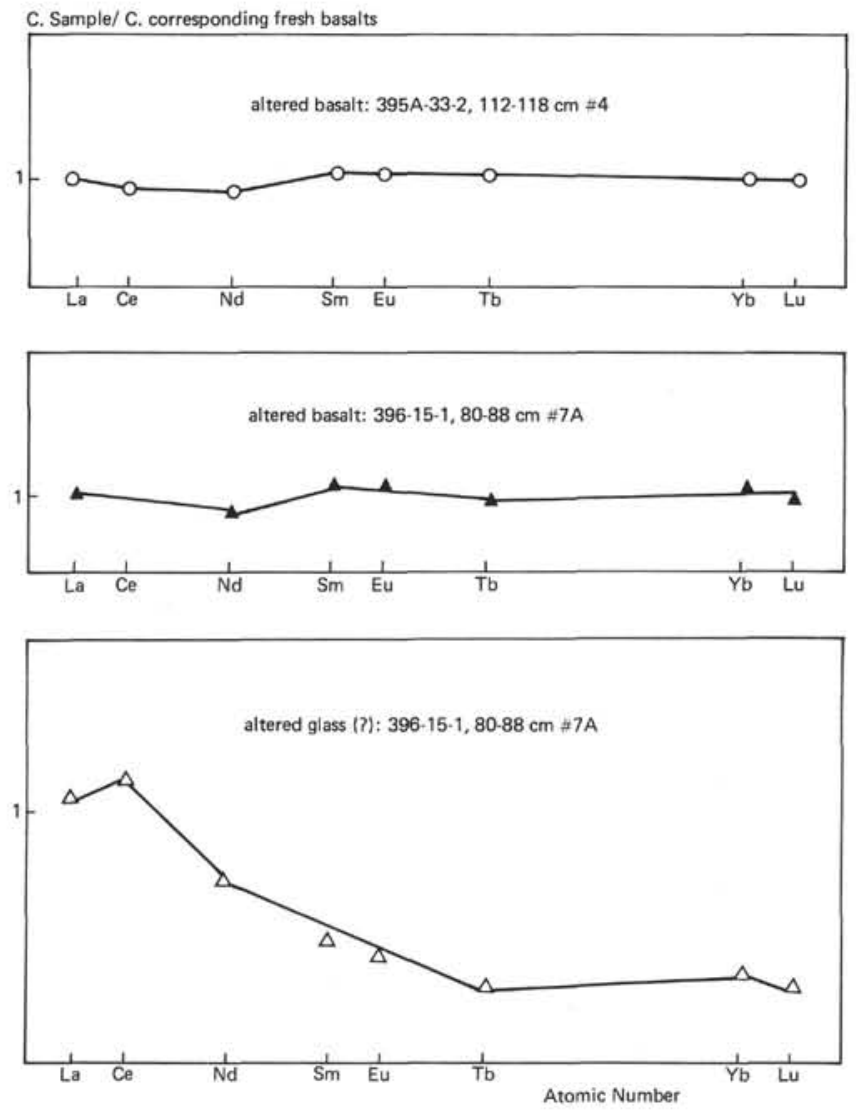

Figure 4. REE curves of altered basalts normalized to corresponding fresh basalts in contact with them.

earths abundance patterns, J. Geophys. Res., v. 68, p. 559566.

Frey, F. A. and Haskin, L. A., 1964. Rare earths in oceanic basalts, J. Geophys. Res., v. 69, p. 775-780.

Honnorez, J., 1972. La palagonitisation: l'altération sous-marine du verre volcanique basique de Palagonia (Sicile), Kristallogr. Petrograph. Institut der Eidgenössischen Technischen Hochschule Zürich No. 9.

Moore, J. G., 1966. Rate of palagonitization of submarine basalt adjacent to Hawaii., U. S. Geol. Survey Prof. Paper 550-D, p. D163-D171.

Mumpton, F. A. and Ormsby, W. C., 1976. Morphology of zeolites in sedimentary rocks by scanning electron microscopy, Clays and Clays Minerals, v. 24, p. 1-23.

Person, A., 1976. Recherches sur les néoformations argileuses dans l'environment volcanique, Thése 3ème cycle, Paris VI, p. 166. 
Ronov, A. B., Balashov, Yu, A., and Migdisov, A. A., 1967. Geochemistry of the rare earths in the sedimentary cycle, Geochem. Intern. v. 4., p. 1-17.

Senderov, E. E., 1965. Features of the conditions of zeolite formation, Geochem. Intern., 2, p. 1143-1155 (translated by Dr. Zen).

Steinberg, M. and Courtois, C., 1976. Le comportement des terres rares au cours de l'altération et ses conséquences, Bull. Soc. Géol. France, v. XVIII, p. 13-20.
Stokes, K. R., 1971. Further investigations into the nature of the materials chlorophaeite and palagonite, Mineralogical Magazine, v. 38, p. 205-214.

Treuil, M., Jaffrezic, H., Deschamps, N., Derre, C., Guichard, F., Joron, J. L., Pelletier, B., Courtois, C., and Novotny, S., 1973. Analyse des lanthanides, du hafnium, du scandium, du chrome, du manganèse, du cobalt, du cuivre et du zinc dans les minéraux et les roches par activation neutronique, J. Radioanal. Chem., v. 18, p. 55-68. 


\section{PLATE}

Early Stages of Alteration in Colorless Isotropic Glass of Hyaloclastic Fragments

Figure 1 Photomicrograph of small brownish striated and lobated areas in the colorless isotropic glass, central zone of a hyaloclastic fragment. These areas often develop around fresh olivine micro-phenocrysts (OL).

Sample 395A-59-1, 44-48 cm \#6; magnification $\times 35$; plane polarized light.

Figure 2 Photomicrograph of small brownish striated and lobated areas in the colorless isotropic glass, central zone of a hyaloclastic fragment. Sample 395A-58-2, 75-81 cm \#6c; magnification $\times 35$, plane polarized light.

Figure 3

Detail of Figure 1, by crossed polars: the brownish striated areas are anisotropic and polarize to first order white; they are probably composed of crystallized zeolitic material around fresh olivine crystals (OL). Magnification $\times 137$.

Figure 4 Figure 2 by crossed polars, showing same phenomena (olivine microphenocrysts are not visible here). 
PLATE 1
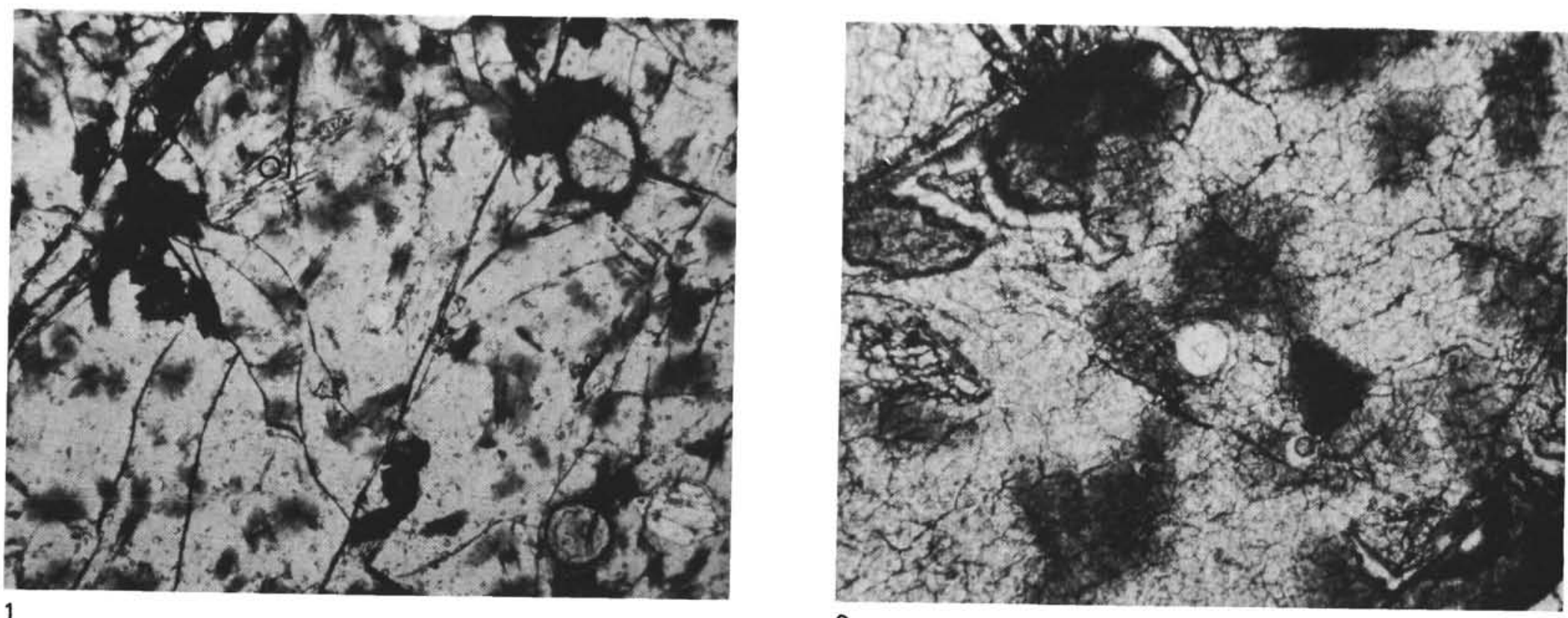

2
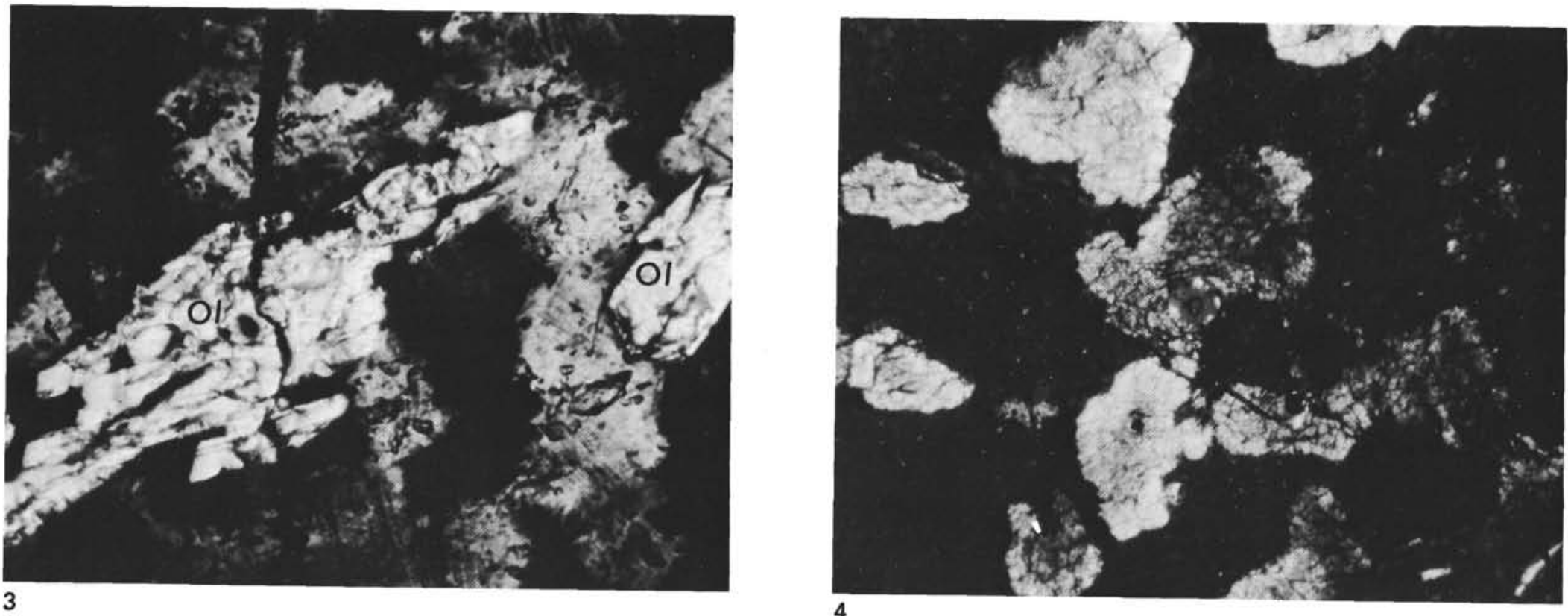

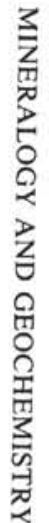


PLATE 2

Intermediate Stages of Palagonitization in Hyaloclastic Fragments

Figure 1 Photomicrograph of brownish striated anisotropic areas in colorless isotropic glass, now surrounded by a thin fibrous rim of zeolitessmectites.

Sample 395A- 58-2, 75-81 cm \#6c; magnification $\times 35$; polarized light.

Figure 2

Detail of Figure 1; magnification $\times 137$.

Figure 3

Photomicrograph showing the altered margins of two isotropic glassy fragments set in a zeolitic cement. The upper right one shows the three alteration rims of the second type of alteration: Zone B: orange isotropic glass, with some anisotropic areas; note the anisotropic zone well developed around the olivine microphenocryst. Zone C: slightly brownish anisotropic rim. Zone D: fibrous anisotropic rim.

Sample 395A- 67-1, 130-137 cm; magnification $\times 137$; plane polarized light.

Figure 4 Figure 3, by crossed polars. 

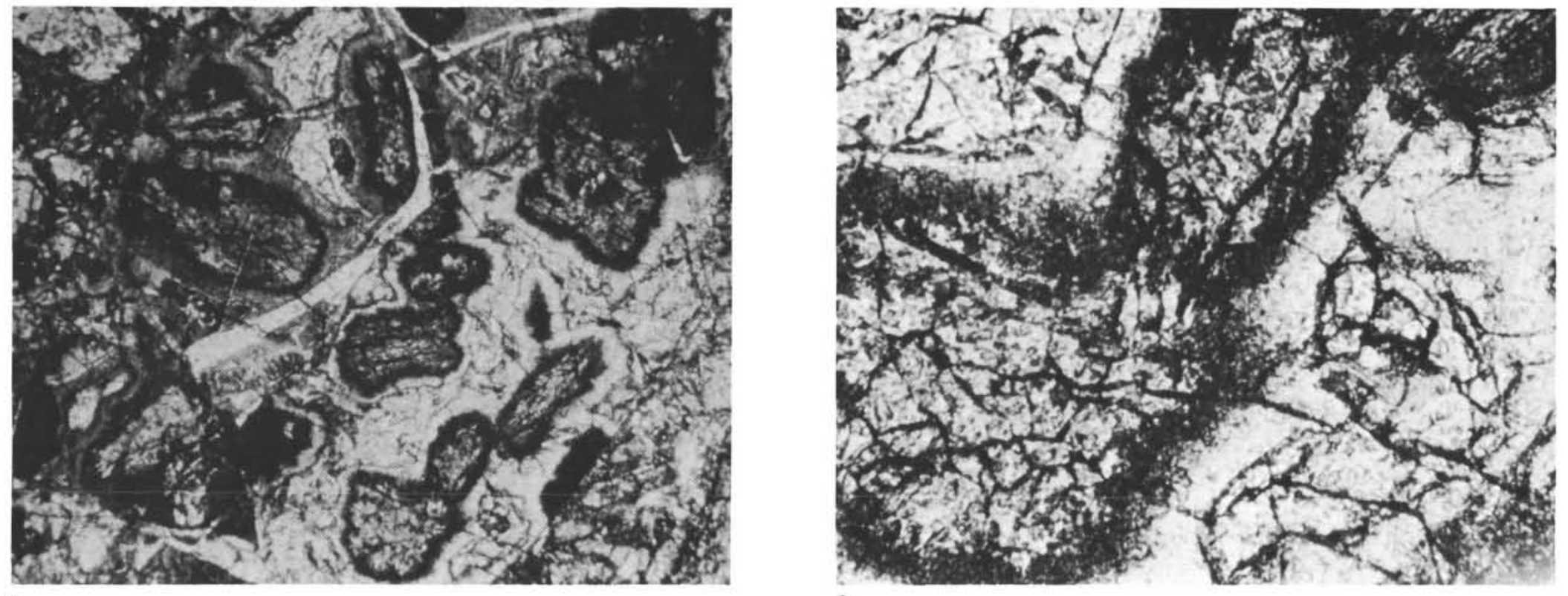

1
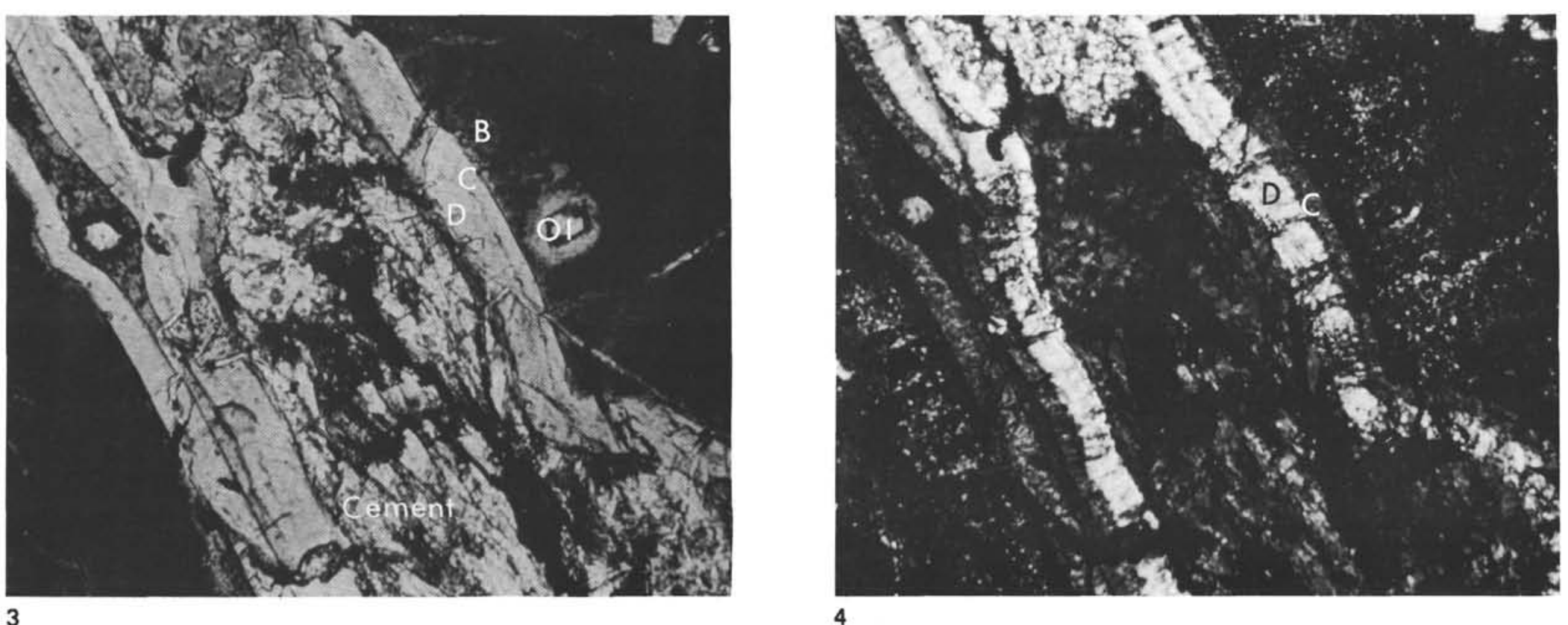


\section{PLATE 3}

Altered Margins of Glassy Fragments in Hyaloclastic Breccias

Figure 1 Photomicrograph of palagonitized glassy fragments cemented by zeolites. Two main zones are visible in the fragment (alteration type 1, see text): Zone A: colorless isotropic glass. Zone B: orange-brown isotropic altered glass, in places slightly anisotropic. The two thin outer rims (Zones $\mathrm{C}$ and $\mathrm{D}$, see text) are not clearly visible here.

Sample 395A-67-1, 130-137 cm; magnification $\times 35$; plane polarized light.

Figure 2 Photomicrograph of palagonitized glassy fragments (type 1), with the different concentric rims $\mathrm{A}, \mathrm{B}, \mathrm{C}+\mathrm{D}$ (together, because they are very thin) clearly visible. Notice that the small shards of glass in the middle are completely altered: their central zone is made of brownish altered glass B.

Sample 395A-59-1, 44-48 cm \#6; magnification $\times 35$; plane polarized light.

Figure 3 Detail of Figure 2: the zones C (slightly brownish anisotropic rim) and D (fibrous outer rim) are clearly visible now. Fan-shaped radiating phillipsite of the cement has nucleated on the boundary of the fragment. Magnification $\times 137$; plane polarized light. 


\section{PLATE 3}
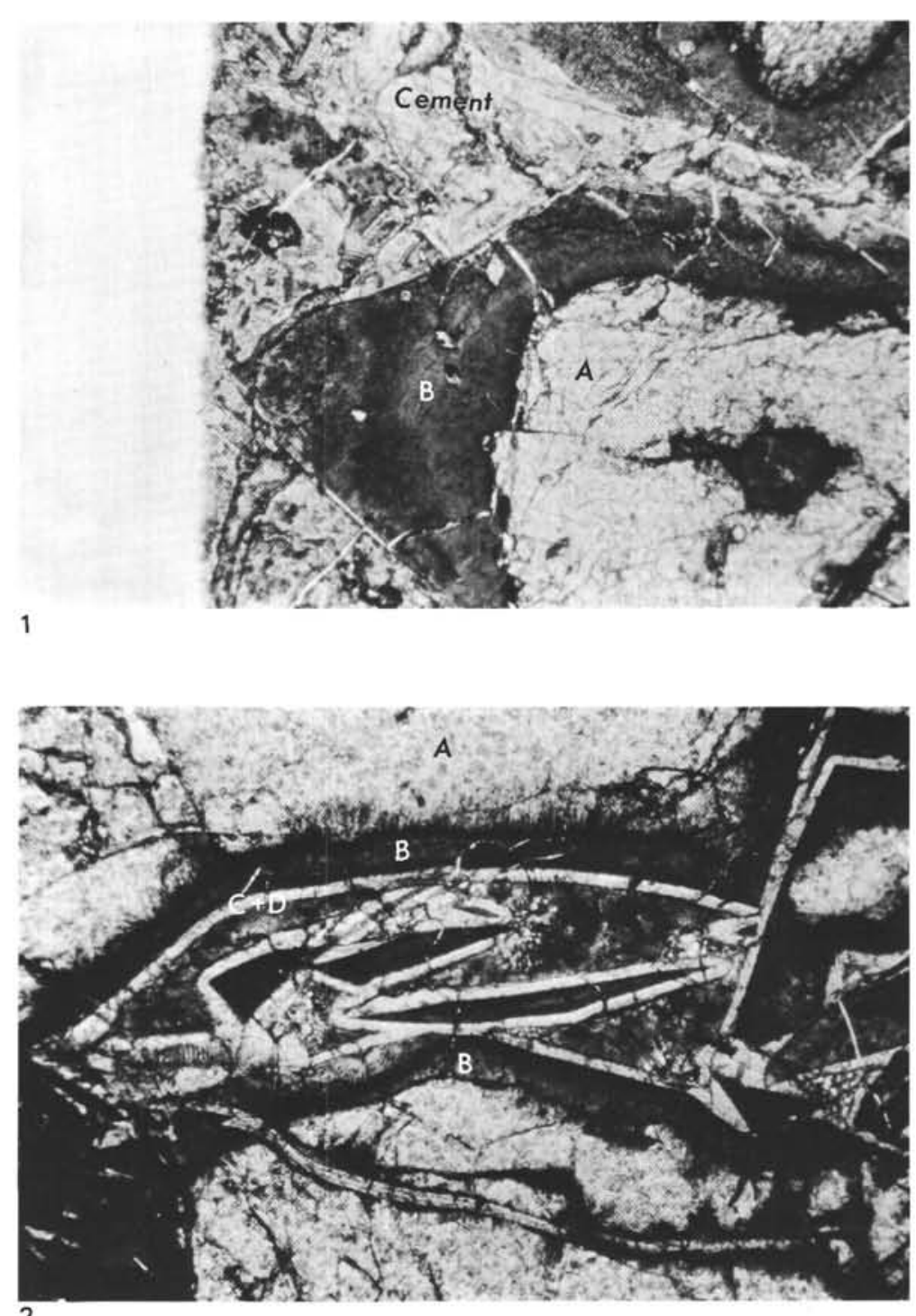

2

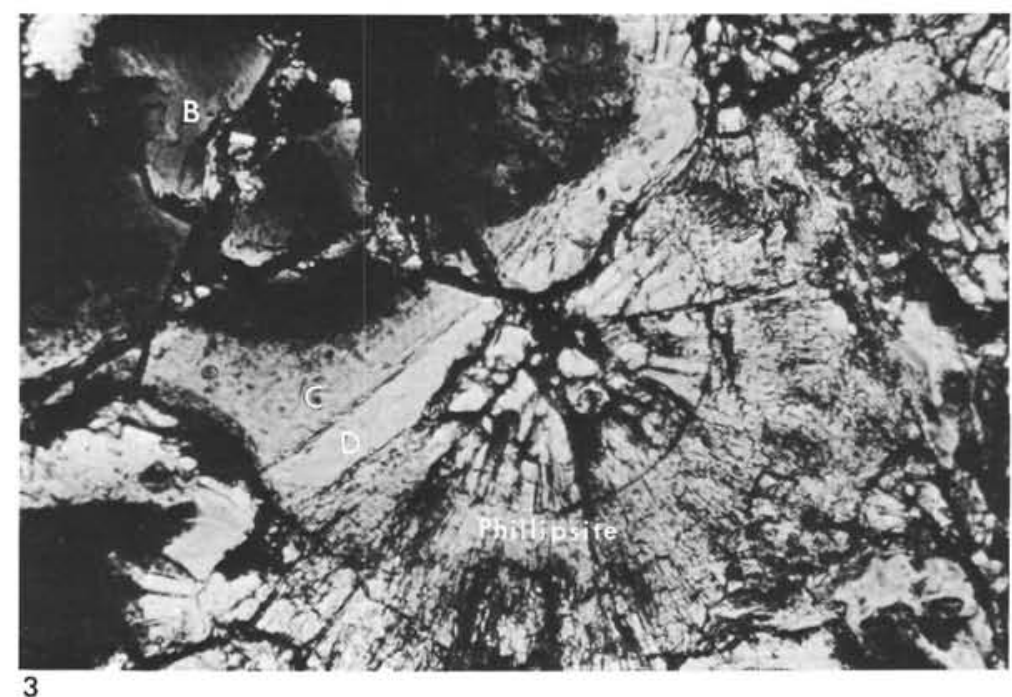




\section{PLATE 4}

Altered Margins of Glassy Fragments in Hyaloclastic Breccias

Figure 1 The two types of alterations described in the text are visible here: (1) The big fragment margin in the lower part shows the four Zones A, B, C, D of the first type, with a well-developed intermediate brownish Zone B. (2) In the center of the photograph, a small fragment exhibits the sharp transition from fresh glass $A$ to the thin outer rims, without intermediate brownish glass. This part is enlarged in the following figures.

Sample 395A-58-2, 75-81 cm \#6c; magnification $\times 35$; plane polarized light.

Figure 2 Detail of Figure 1, showing the typical zones of the second type of alteration: Zone A: colorless isotropic glass; Zone B: green, slightly anisotropic rim; Zone C: very thin, slightly brownish anisotropic rim; Zone D: fibrous outer rim (zeolites + chlorites). Magnification $\times 137$; plane polarized light.

Figure 3 Idem, crossed polars. 
PLATE 4
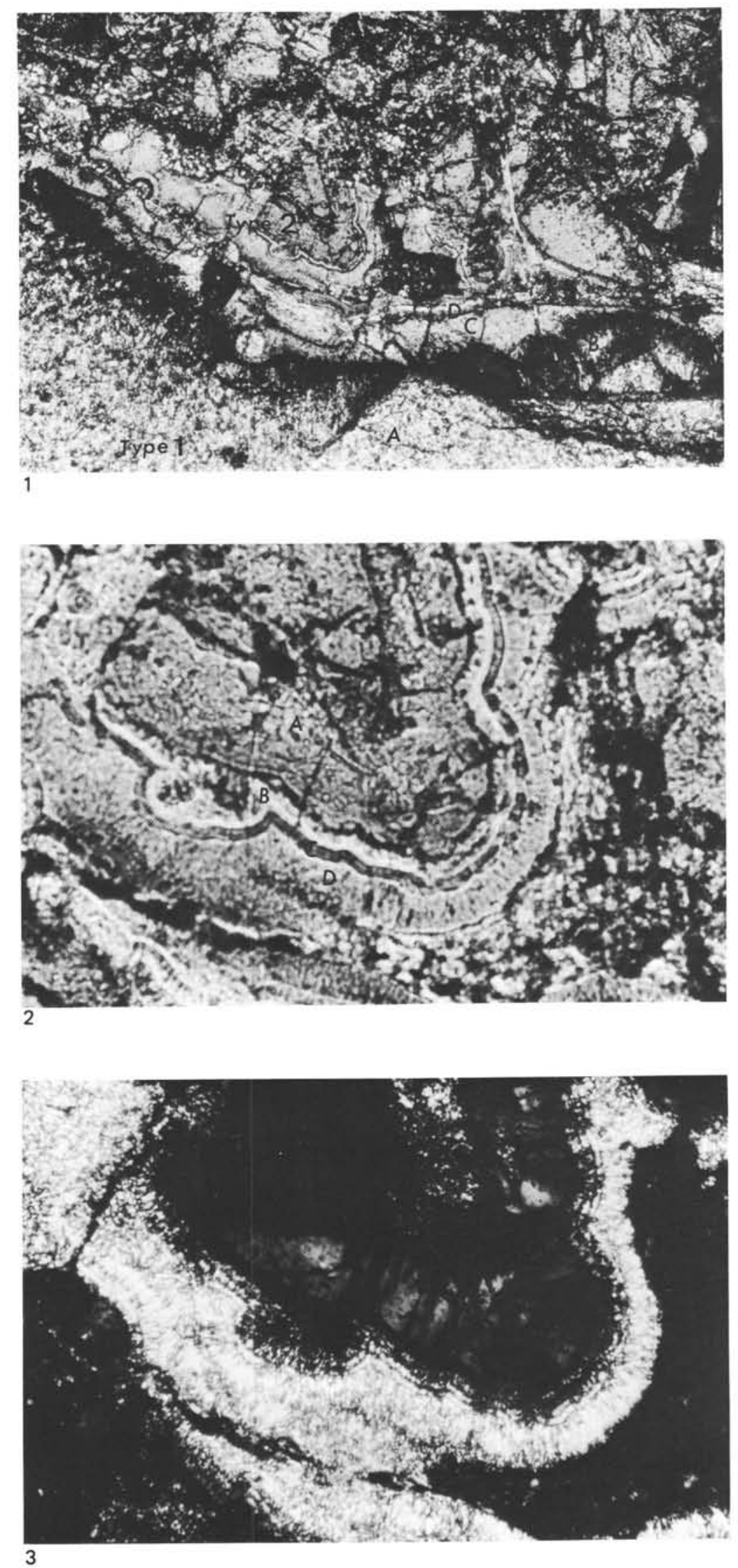
PLATE 5

Secondary Minerals in Vesicles

Figure 1 Photomicrograph of a small vesicle filled with zeolites and smectites, cut by a calcitic veinlet, in an aphyric basalt.

Sample 395A-65-2, 70-90 cm; magnification $\times 35$; plane polarized light.

Figure 2 Detail of Figure 1; magnification $\times 137$; crossed polars. 
PLATE 5
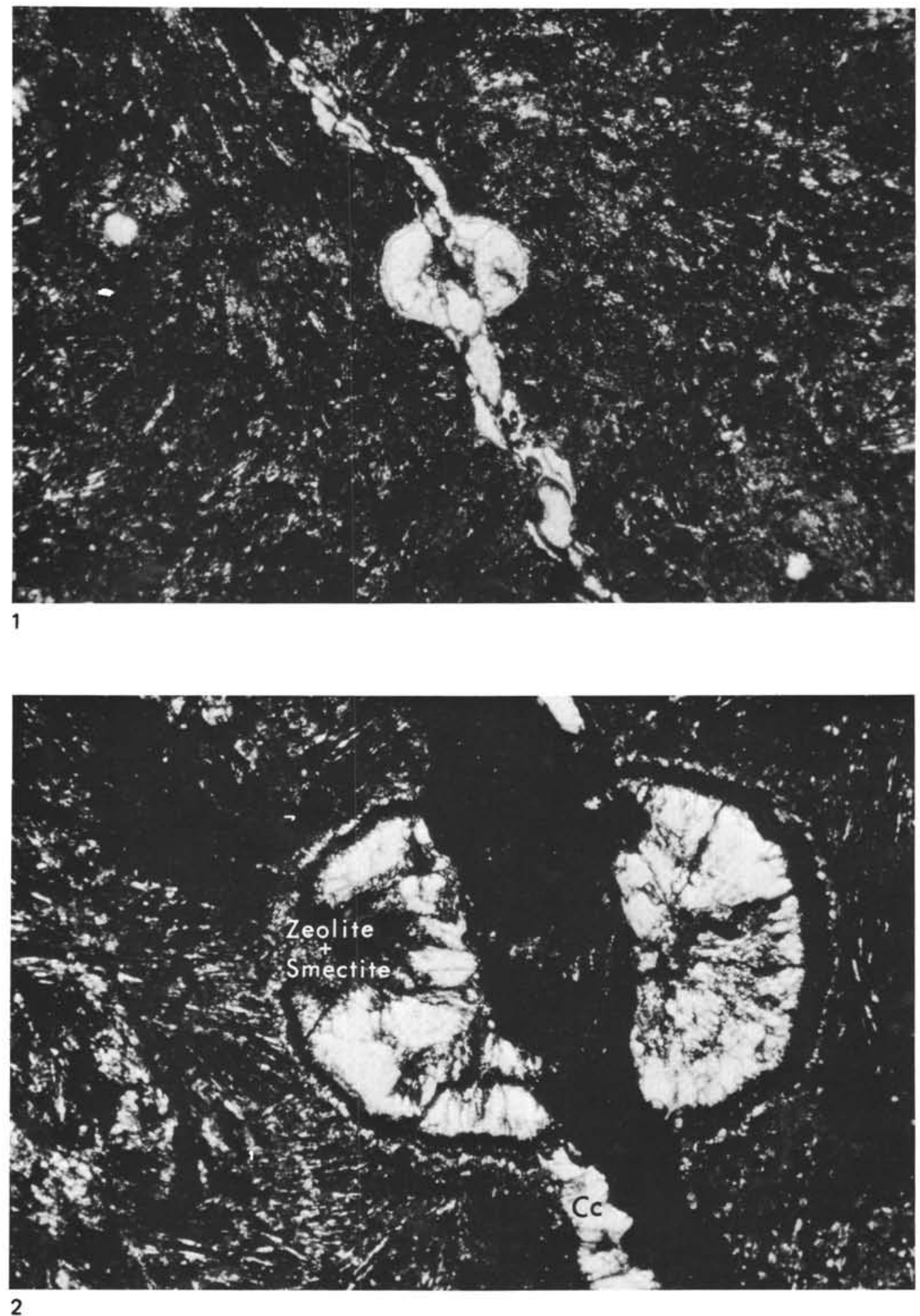
PLATE 6

Coating of an Open Fracture

Figure 1 Three kinds of minerals are visible: (1) a thin pale green coating covering the whole surface of the fracture (smectites); (2) white opaque minerals forming radiating spherules, rather abundant and irregulary disposed over the surface (stilbite); (3) scarce translucent minerals (phillipsite).

Sample 395A-63-4, 80-88 cm.

Figure 2 Detail of Figure 1. 


\section{PLATE 6}
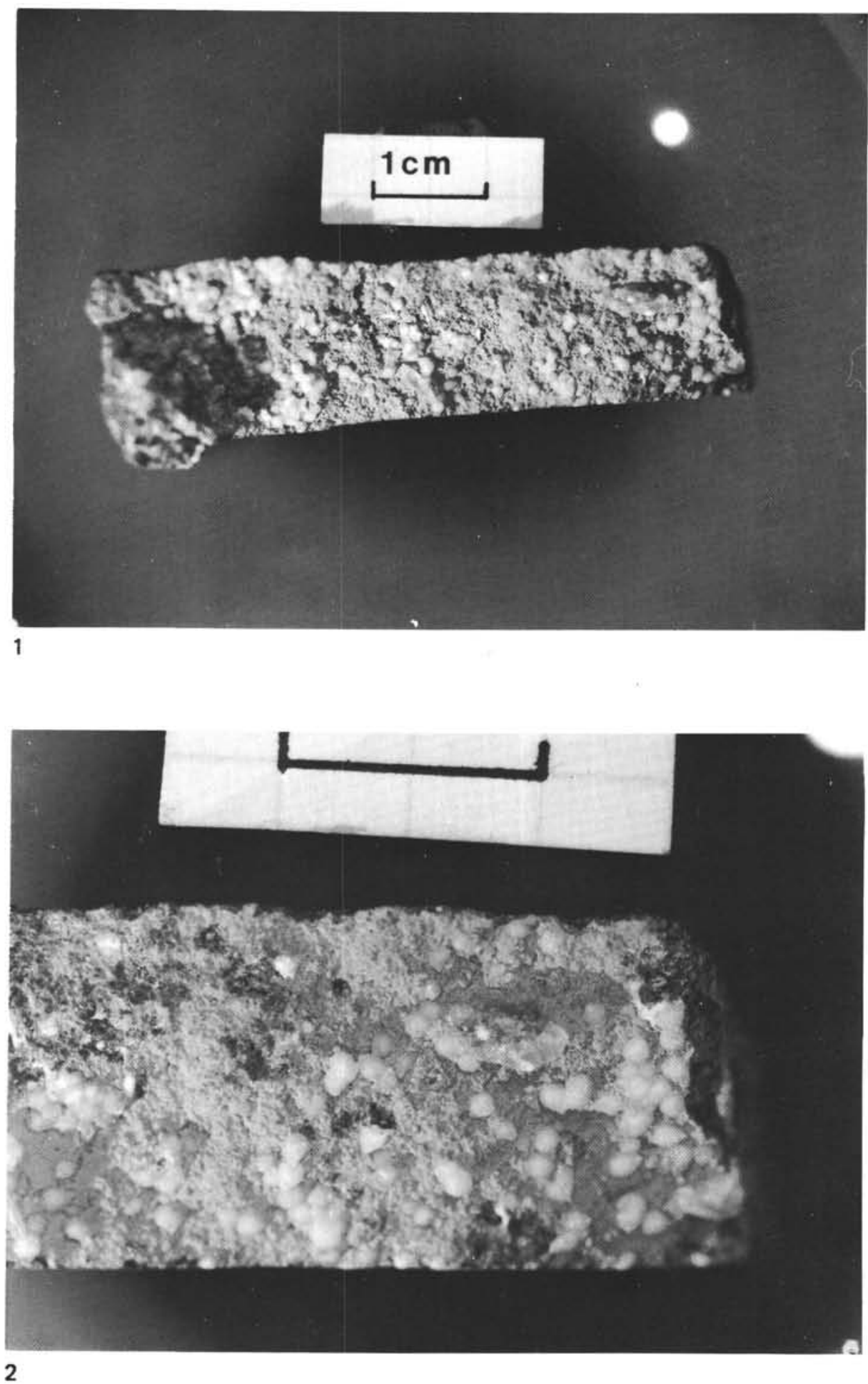
PLATE 7

Coating of an Open Fracture: Morphology of the Green Concretions, by Scanning Electron Microscopy

Figure 1 Spherules of green smectites, $\times 350$. (Negative SEM 761232.)

Figure 2 Internal radiating structure of one spherule, ×900. (Negative SEM 761229.)

Figure 3 Detail of the surface of a spherule, showing the characteristic morphology of neoformed smectites, $\times 4000$. (Negative SEM 761285.)

Figure 4 Detail of Figure 3, $\times 10,000$. (Negative SEM 761286.) 
PLATE 7
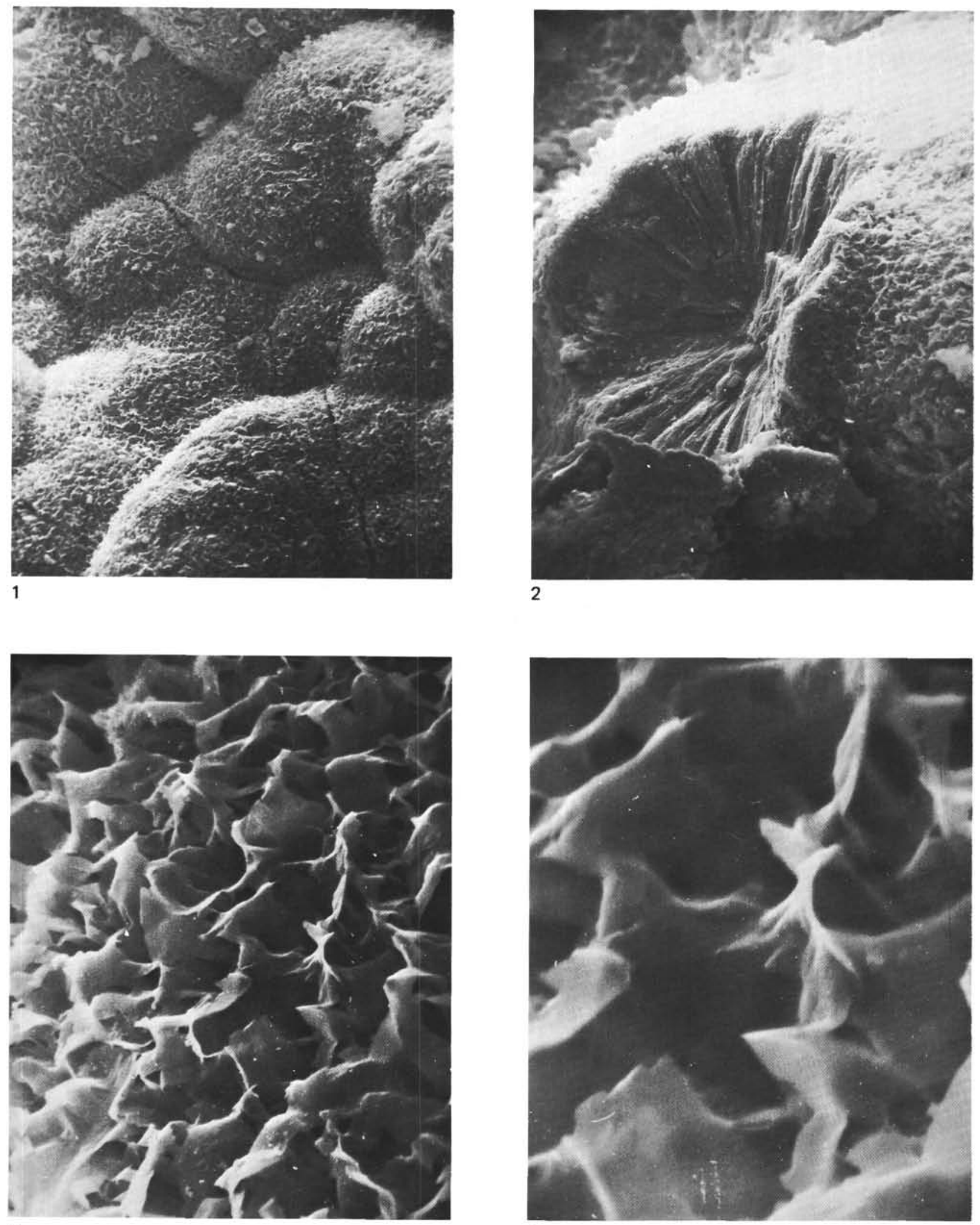
PLATE 8

Coating of an Open Fracture: Morphology of the White Opaque Concretions, by Scanning Electron Microscopy

Figure 1 General morphology of the stilbite concretions: "fusiform", balls, $\times 30$. (Negative SEM 761231.)

Figure 2 Idem, general morphology of the "fusiform" balls, $\times 35$. (Negative SEM 761233.)

Figure 3 Detail of the "roofing tile" disposition of the stilbite crystals in the balls. Notice the presence of a re-entrant angle in each "tile," which is formed by two twinned stilbite crystals. $\times 400$. (Negative SEM 761288.)

Figure 4 Detail of a "tile." $\times 4000$. (Negative SEM 761287.) 
PLATE 8

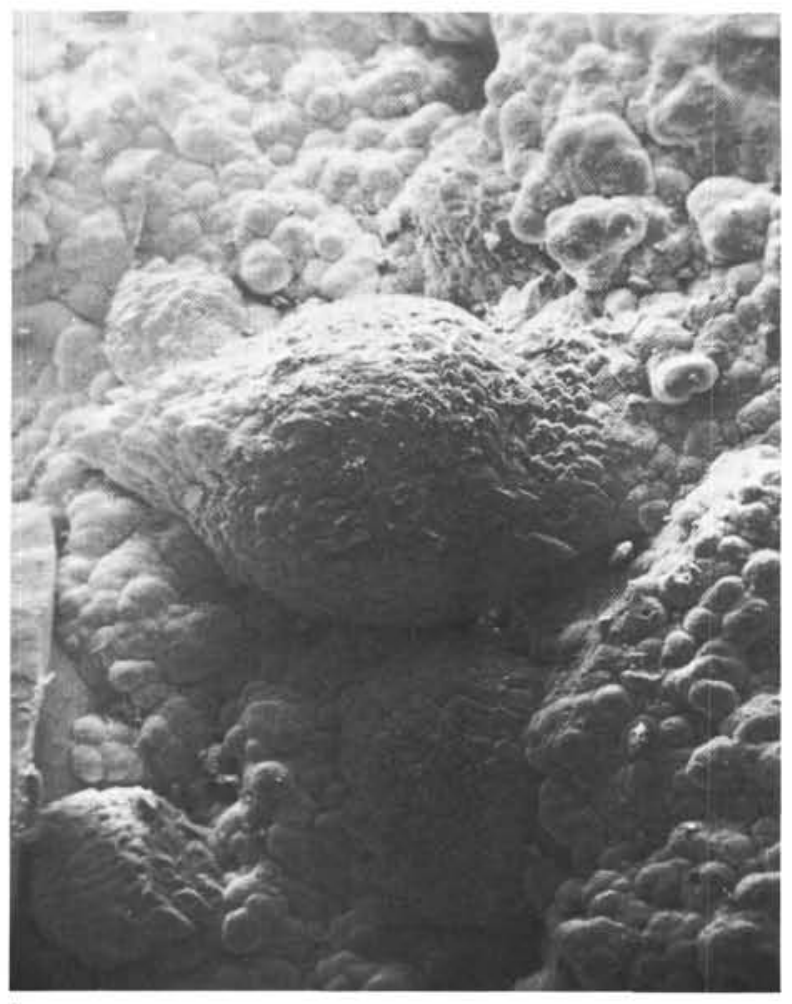

1

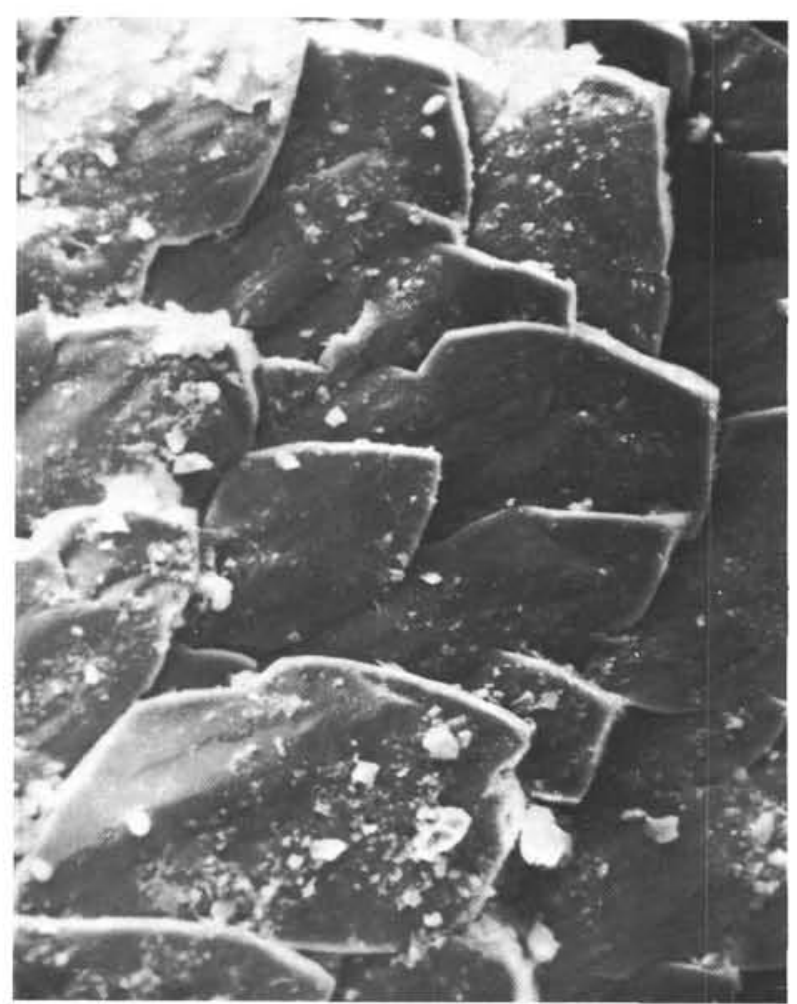

3

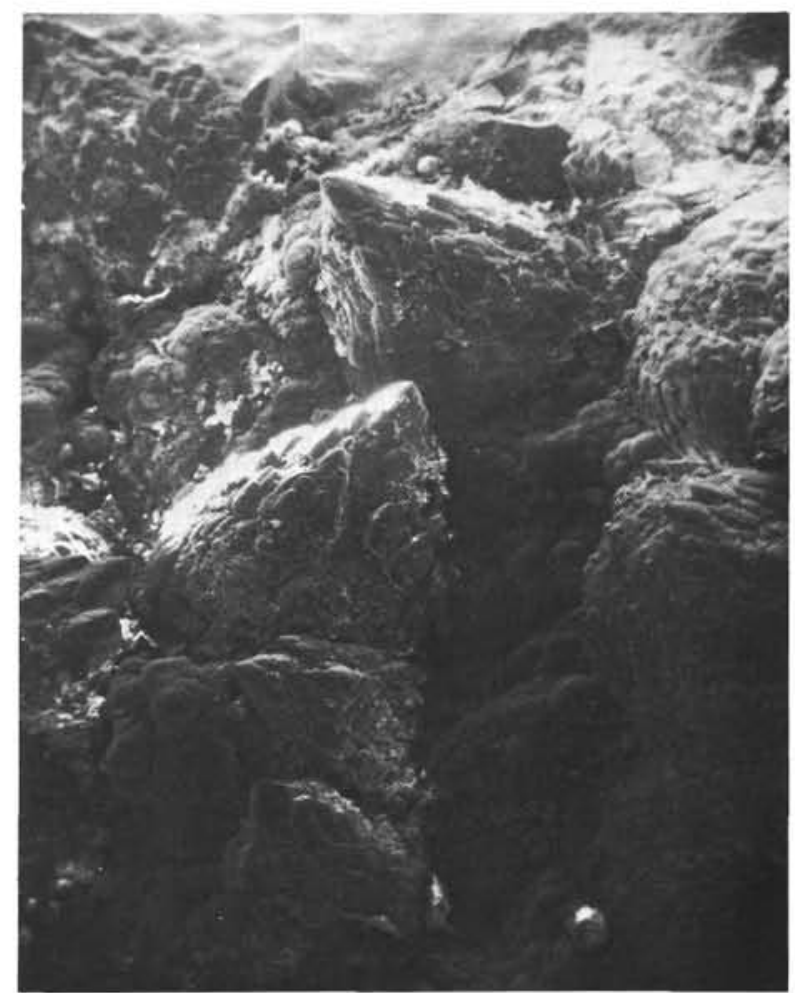

2

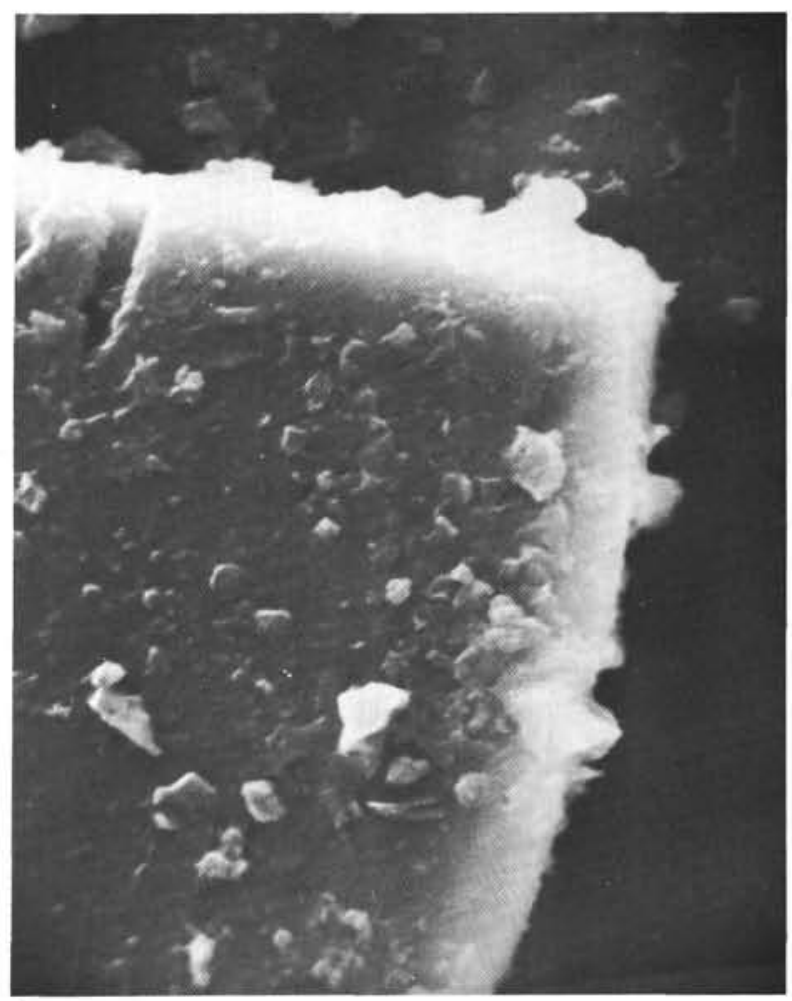

4 
PLATE 9

Coating of an Open Fracture: Morphology of the Scarce Translucent Crystals, by Scanning Electron Microscopy

Figure 1 Morphological aspect of a fragment of phillipsite, made of lamellae piled up on one another. $\times 700$. (Negative SEM 761291.)

Figure 2 Morphological aspect of the phillipsite crystal, intensely fractured by the electron beam under vacuum. $\times 30$. (Negative SEM 761290.)

Figure 3 Detail of the lamellae, $\times 3000$. (Negative SEM 761292.)

Figure $4 \quad$ Another aspect of the piling up of the lamellae. $\times 900$. (Negative SEM 761235.) 


\section{PLATE 9}
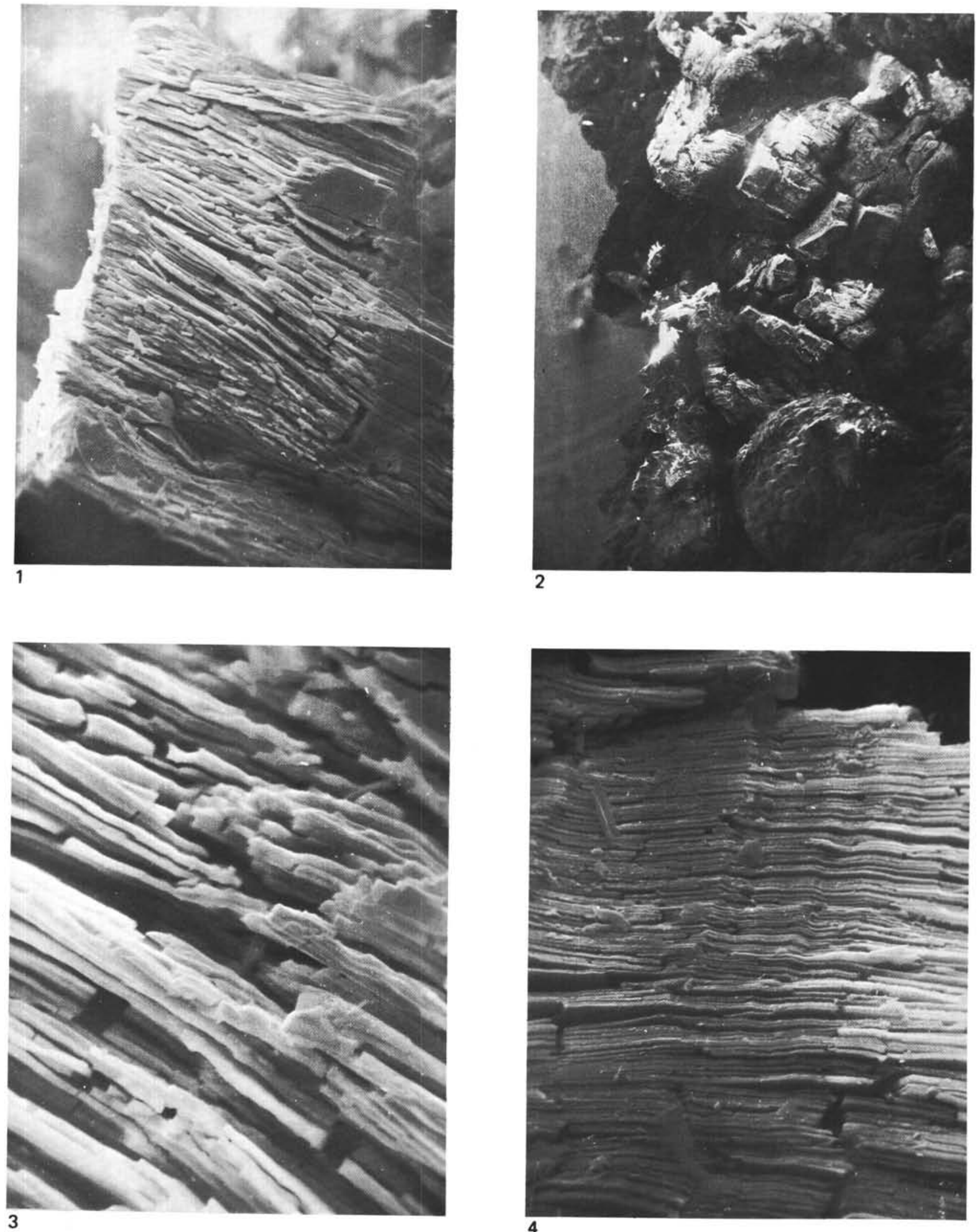
PLATE 10

Serpentines and Associated Minerals in Leg 45 Harzburgites

Figure 1 Mesh serpentine (chrysotile), around olivine relicts. Serpentinized harzburgite. Crossed polars; magnification $\times 7.5$;

Sample 395-18-2, 62-70 cm \#15.

Figure 2 Mesh serpentine with fibrous serpentine $\mathrm{CHR}=$ chrysotile) and olivine relicts in the meshes. Serpentinized harzburgite, crossed polars. Magnification $\times 48$;

Sample 395-18-2, 62-70 cm \#15.

Figure 3 Serpentinization of orthopyroxene (enstatite). The serpentine is a bastite (=flaky lizardite) with its main cleavage $(001)$ oriented parallel to the cleavage (100) of pyroxene. Serpentinized harzburgite, crossed polars. Magnification $\times 48$;

Sample 395-18-2, 62-70 cm \#15.

Figure 4 Talc (TA) cutting orthopyroxene (enstatite). Serpentinized harzburgite, crossed polars. Magnification $\times 7.5$;

Sample 395A-18-2, 45-50 cm \#2.

Figure 5 Chlorite vein in a serpentinite. Crossed polars. Magnification $\times 48$;

Sample 395-18-2, 7-10 cm \#2.

Figure 6 Carbonate veins ( $\mathrm{AR}=$ aragonite) in a serpentinite. Crossed polars. Magnification $\times 7.5$; Sample 395-18-2, 7-10 cm \#2. 
PLATE 10
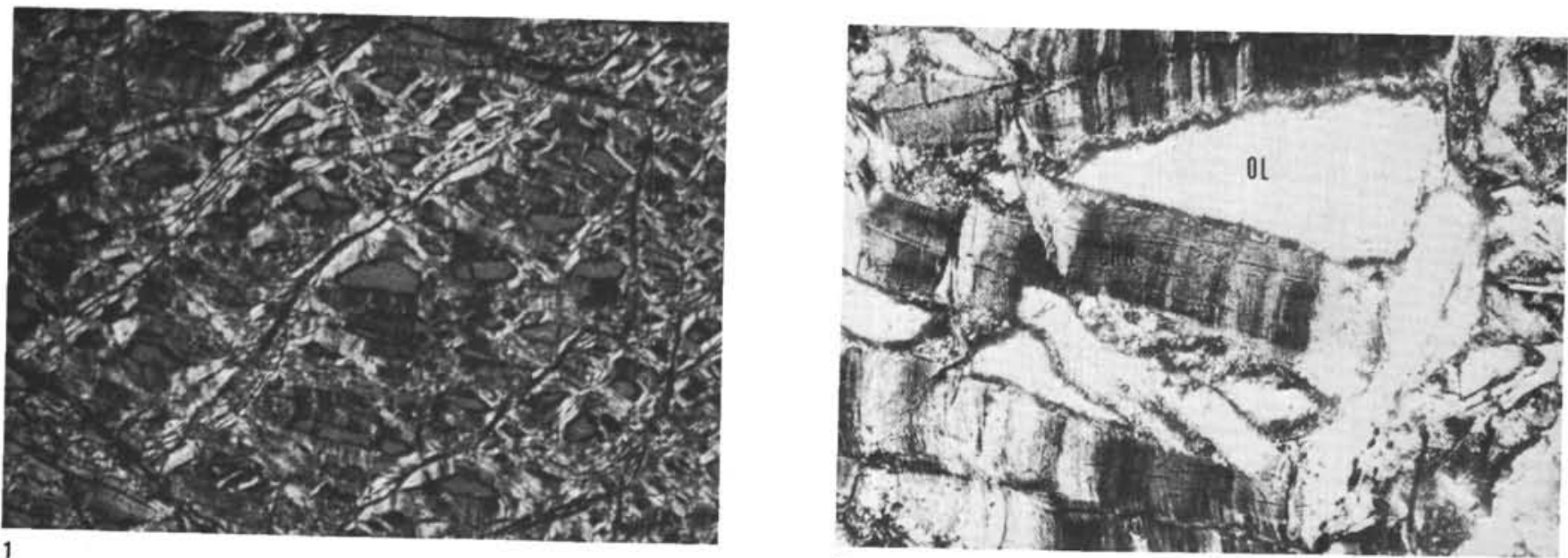

2
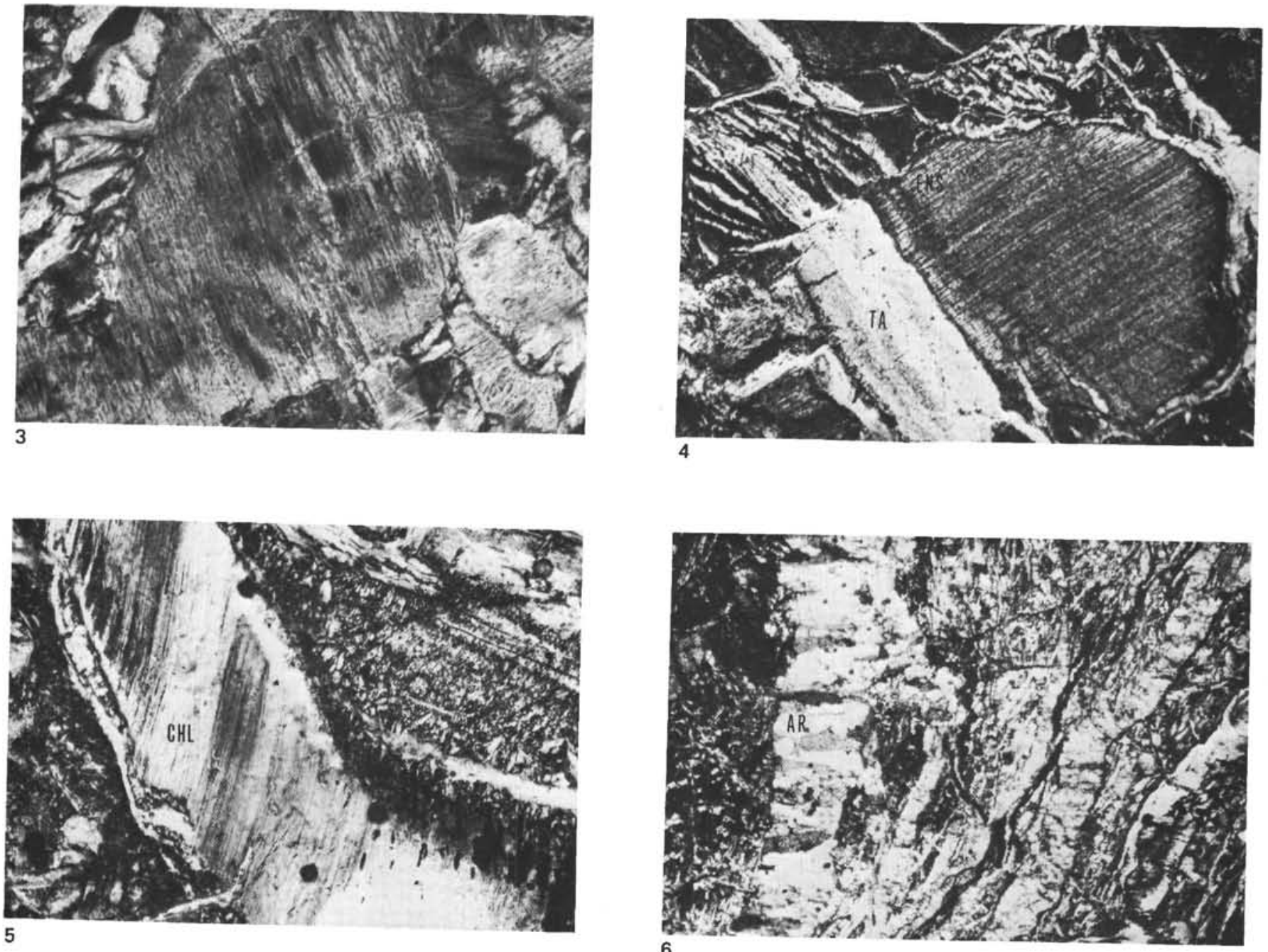
PLATE 11

Serpentines and Associated Minerals in Leg 45 Harzburgites

Figure 1 Chrysotile, (left) electron micrograph of a dispersion and (right) an electron-diffraction pattern from a single crystal. $\times 45,000$.

Sample 395A-4-2, 45-50 cm \#2.

Figure 2 Lizardite, (left) electron micrograph of a dispersion and (right) an electron-diffraction pattern from a crystal. $\times 60,000$.

Sample 395-18-2, 7-10 cm \#2.

Figure 3 Talc (left) electron micrograph of a dispersion of talc (platy aggregate) and chrysotile and (right) an electron-diffraction pattern from a crystal of talc. $\times 60,000$.

Sample 395A-4-2, 45-50 cm \#2. 
PLATE 11
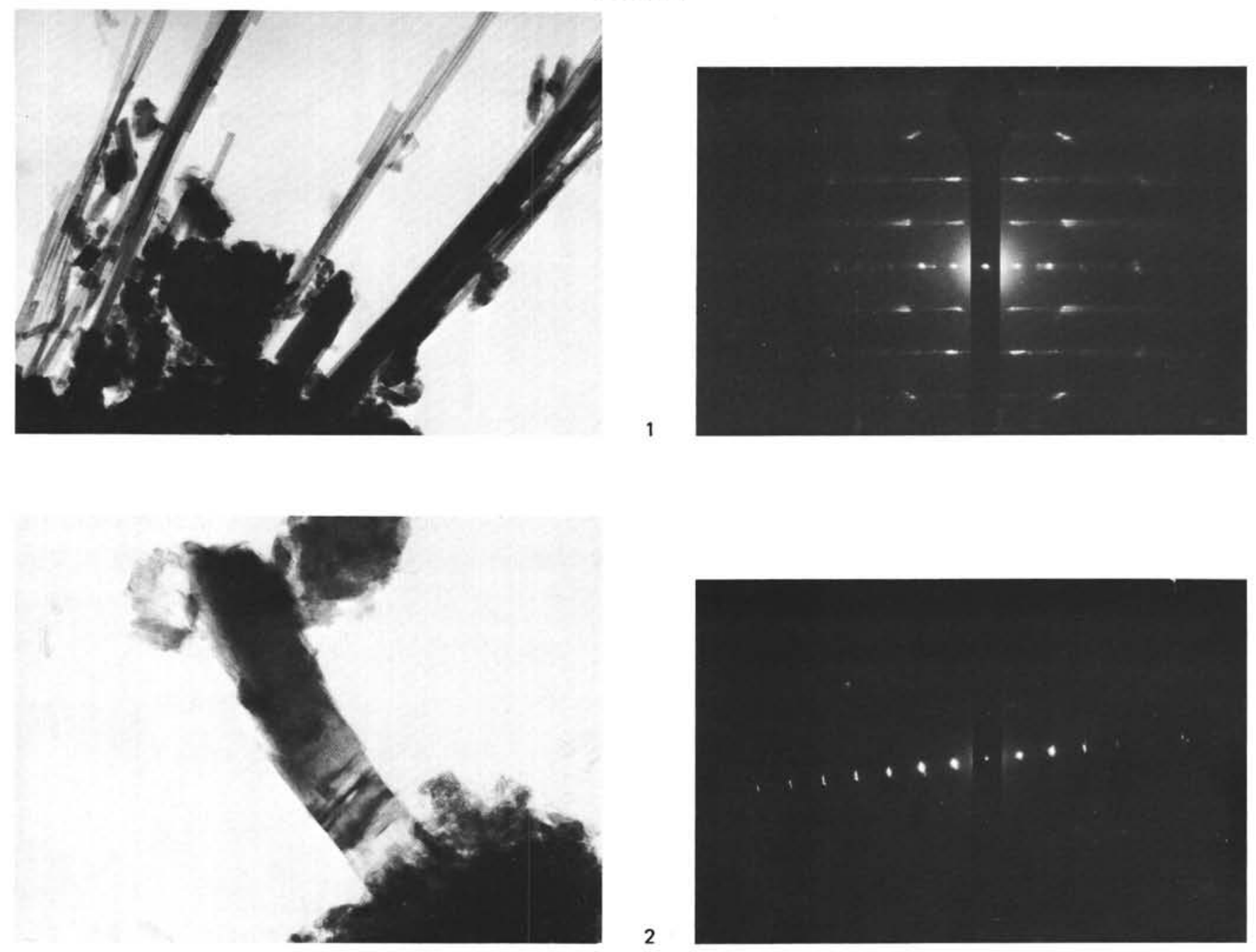

2
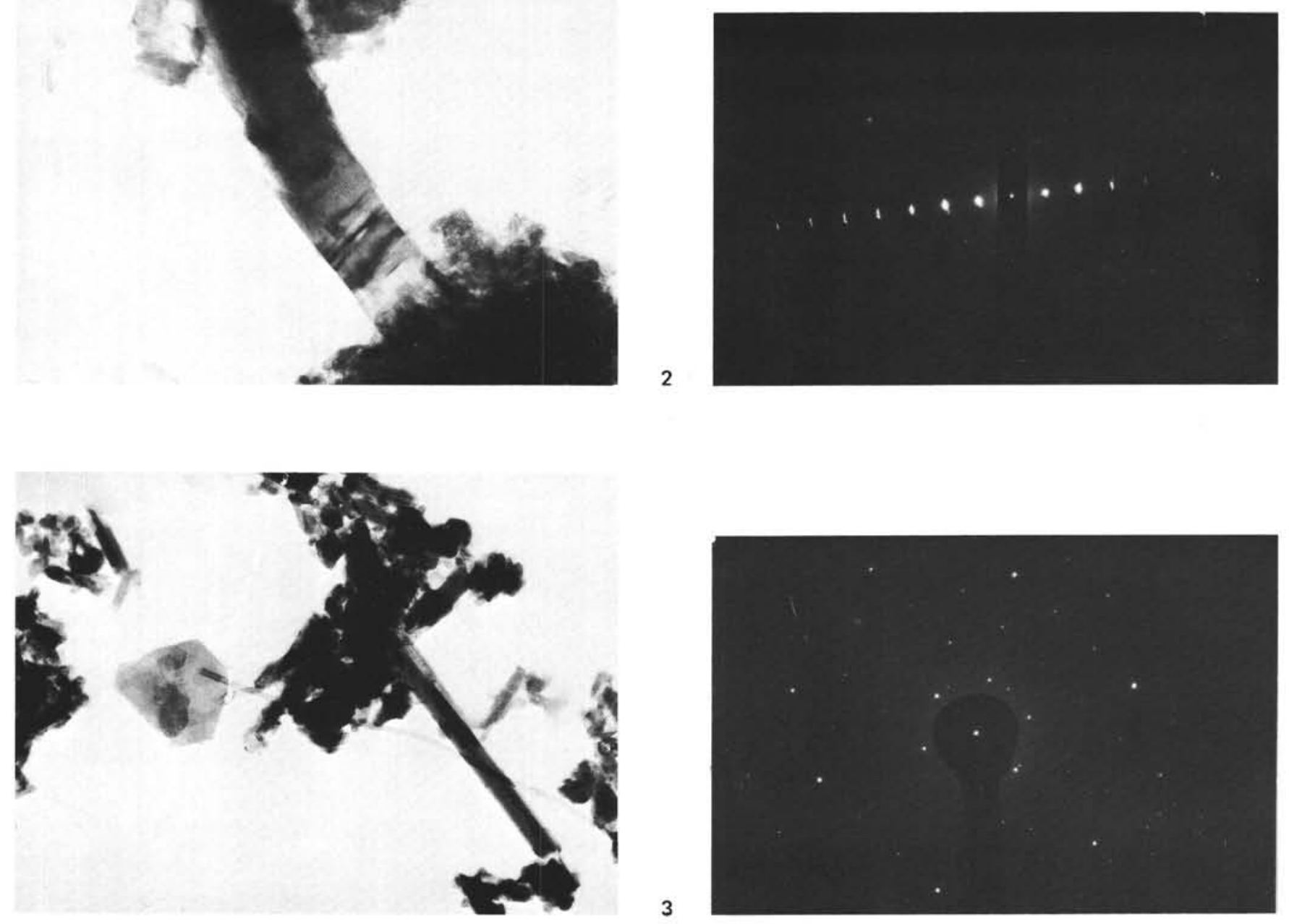
PLATE 12

Serpentines and Associated Minerals in Leg 45 Harzburgites

Figure 1 Chlorite, (left) electron micrograph of a dispersion and (right) an electron-diffraction pattern from a single crystal. $\times 37,500$.

Sample 395-18-2, 7-10 cm \#2.

Figure 2 Carbonate (Dolomite), (left) electron micrograph of dispersion and (right) an electron-diffraction pattern from a crystal. $\times 48,000$.

Sample 395-18-2, 138-141 cm \#17f.

Figure 3 Goethite (left) electron micrograph of a dispersion and (right) an electron-diffraction pattern from a crystal. $\times 37,500$.

Sample 395-18-1, 101-106 cm \#2g. 
PLATE 12
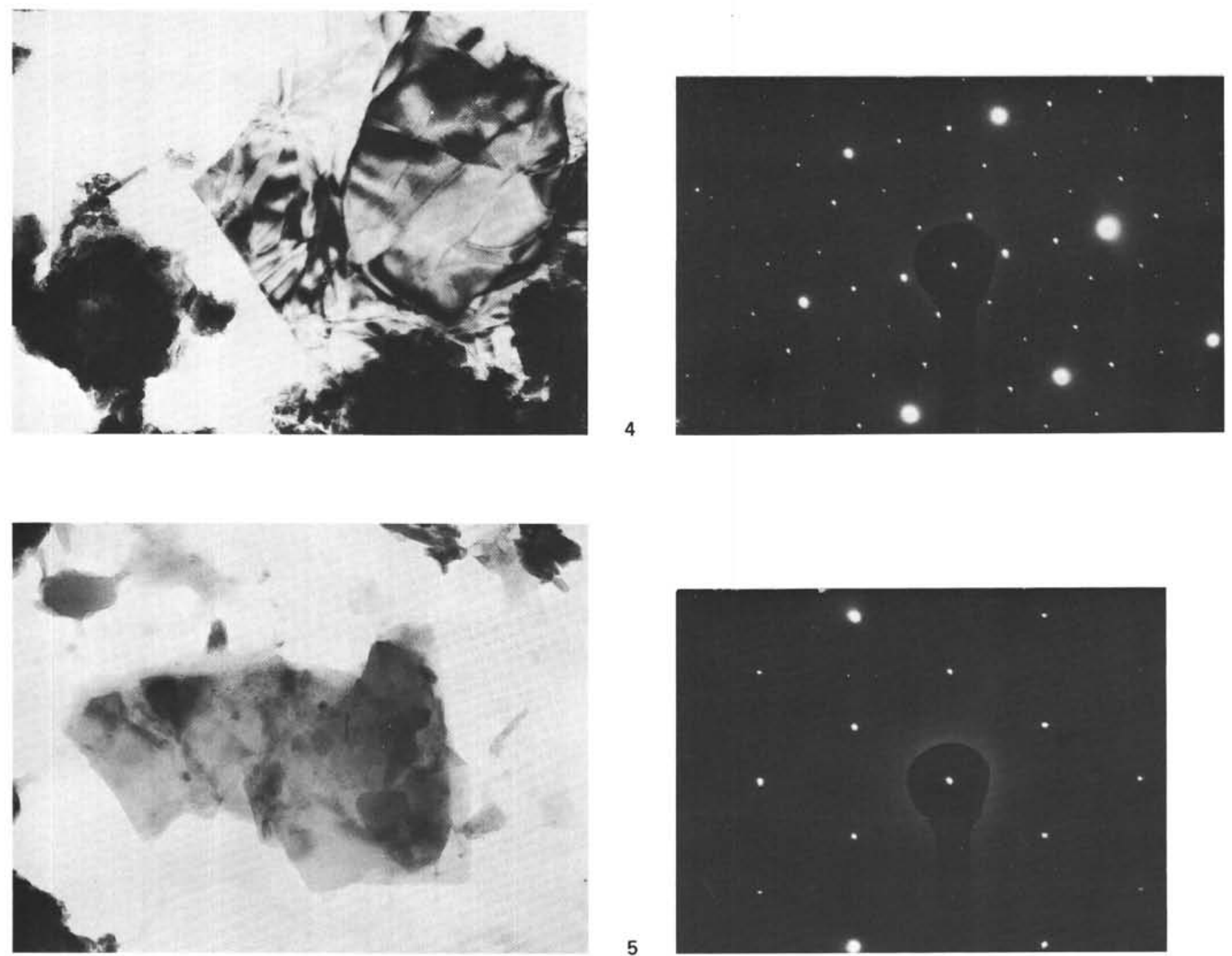

5
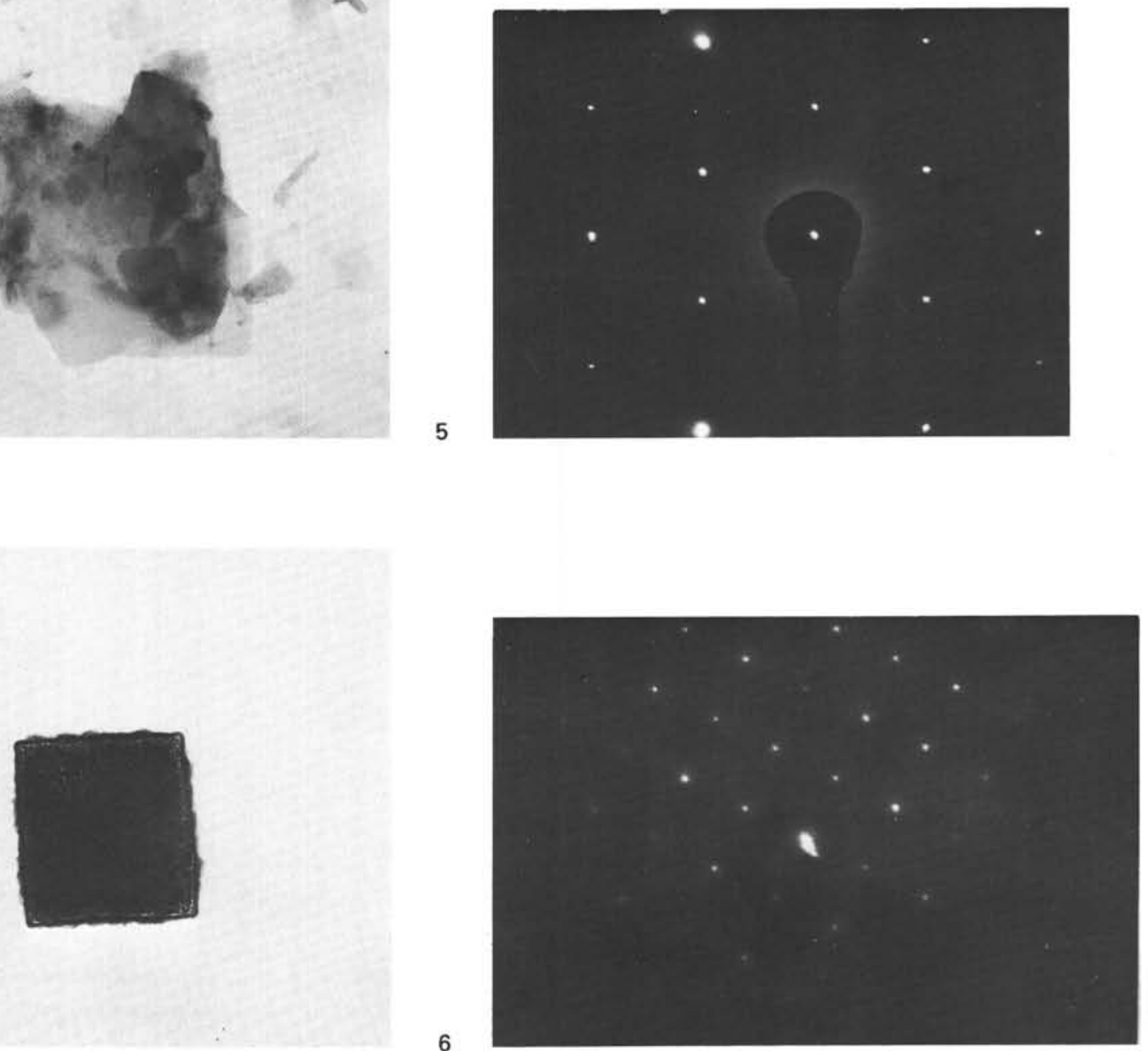